\title{
MASTER
}

\section{User's Manual for FORAR, A Stand Model for Composition and Growth of Upland Forests of Southern Arkansas}
D. L. Mielke
H. H. Shugart
D. C. West 


\section{DISCLAIMER}

This report was prepared as an account of work sponsored by an agency of the United States Government. Neither the United States Government nor any agency Thereof, nor any of their employees, makes any warranty, express or implied, or assumes any legal liability or responsibility for the accuracy, completeness, or usefulness of any information, apparatus, product, or process disclosed, or represents that its use would not infringe privately owned rights. Reference herein to any specific commercial product, process, or service by trade name, trademark, manufacturer, or otherwise does not necessarily constitute or imply its endorsement, recommendation, or favoring by the United States Government or any agency thereof. The views and opinions of authors expressed herein do not necessarily state or reflect those of the United States Government or any agency thereof. 


\section{DISCLAIMER}

Portions of this document may be illegible in electronic image products. Images are produced from the best available original document. 


\section{Printed in the United States of America. Available from National Technical Information Service \\ U.S. Department of Commerce \\ 5285 Port Royal Road, Springfield, Virginia 22161 \\ Price: Printed Copy $\$ 4.50$; Microfiche $\$ 3.00$}

This report was prepared as an account of work sponsored by the United States Government. Neither the United States nor the Energy Research and Development Administration/United States Nuclear Regulatory Commission, nor any of their employees, nor any of their contractors, subcontractors, or their employees, makes any warranty, express or implied, or assumes any legal liability or responsibility for the accuracy, completeness or usefulness of any information, apparatus, product or process disclosed, or represents that its use would not infringe privately owned rights. 
Contract No. W-7405-eng-26

User's Manual for FORAR, A Stand Model for Composition and Growth of Upland Forests of Southern Arkansas

D. L. Mielke, 'H. H. Shugart, and D. C. West

ENVIRONMENTAL SCIENCES DIVISION

Publication No. 1021

\footnotetext{
${ }^{1}$ Graduate Program in Ecology, University of Tennessee, Knoxville, Tennessee 37916.
}

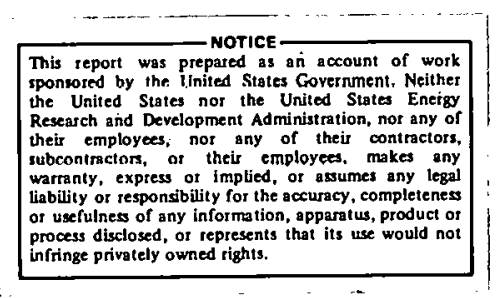

OAK RIDGE NATIONAL LABORATORY

Oak Ridge, Tennessee 37830

operated by

UNION CARBIDE CORPORATION

for the

ENERGY RESEARCH AND DEVELOPMENT ADMINISTRATION 
THIS PAGE

WAS INTENTIONALLY

LEFT BLANK 


\title{
ABSTRACT
}

\author{
MIELKE, D. L., H. H. SHUGART, and D. C. WEST. 1977. User's \\ manual for FORAR, a stand model for composition and \\ growth of upland forests of Southern Arkansas. ORNL/TM- \\ 5767. Oak Ridge National Laboratory, Oak Ridge, Tennessee. \\ $44 \mathrm{pp}$.
}

This report is a user's manual for FORAR, a computer model simulating stand growth and composition of upland forests of south central Arkansas. The model computes: (1) the number and biomass of each tree species, and (2) the $\mathrm{dbh}$, age, and species of each individual tree on a 1/12-ha circular plot. FORAR was developed from FORET (Shugart and West 1977), a modified version of the JABOWA model developed by Botkin et. at. $(1972 a, 1972 b)$. The present version of FORAR considers up to 35 species and 700 trees and has been implemented on IBM 360 series computers.

Once a year trees are stochastically killed or grown and new trees are stochastically planted. Individual trees are killed by a probability function scaled according to the maximum age recorded for the appropriate species. Stocking of new seedlings and sprouts in a given year depends on the computed leaf area index of the plot and the condition of five environmental variables: mineral soil, litter layer, temperature (as expressed by degree-days), wildlife populations, and epidemics. Individual trees grow according to a species-specific optimum growth function modified by climate, available light, competition, and soil moisture. The optimum growth function is a function of the maximum known age, the maximum $\mathrm{dbh}$, and the maximum height recorded for each species.

The driving variable is degree-days. Input consists of 19 general characteristics for each species. Normal output shows total biomass and leaf area on a simulated plot and, for each species, the number of trees on the plot, their dbh's, and their biomass. The model also has options to list all the trees that have died from random causes, logging, and fire. 


\section{THIS PAGE}

\section{WAS INTENTIONALLY \\ LEFT BLANK}


Page

ABSTRACT . . . . . . . . . . . . . . . . . . . . . . .

LIST OF TABLES . . . . . . . . . . . . . . . . . . . . vi v

LIST OF FIGURES . . . . . . . . . . . . . . . . . . . . ix

INTRODUCTION . . . . . . . . . . . . . . . . . . . . . . . 1

PROGRAM DESCRIPTION ............................ 2

INPUT . . . . . . . . . . . . . . . . . . . . . 2

Subroutines . . . . . . . . . . . . . . . . . 6

Subroutine KILL . . . . . . . . . . . . . . . . . 9

Subroutine BIRTH . ...........'. . . . . . . . . . 11

Subroutine GROW . . . . . . . . . . . . . . . . . . 12

OUTPUT . . . . . . . . . . . . . . . . . . 17

REFERENCES . . . . . . . . . . . . . . . . . . . . . 19

Appendix A-1
Program DATGEN . . . . . . . . . . . . . . . . . 21

Appendix A-2
Program GFIX ...................... . . . 23

Appendix A-3
Listing of Program FORAR . . . . . . . . . . . . . $2 b$

Appendix A-4
Sample Output of Program FORAR ............... . . 37 
THIS PAGE

WAS INTENTIONALLY

LEFT BLANK 


\section{LIST OF TABLES}

Table

Page

1 Parameters used in the FORAR model. Table 2 lists the values used for each tree species. See text for explanation of variables... . . . . . . . . . . . . .

2 Parameter values used in the FORAR model. Scientific binomials follow Little (1971) . . . . . . . . . . 7 
THIS PAGE

WAS INTENTIONALLY

LEFT BLANK 


\section{LIST OF FIGURES}

Figure

Page

1 Deck structure and job setup for program FORAR . . . . . . 3

2 Growing degree-day limits DMAX and DMIN for the geographic range of flowering dogwood (Cornus florida). Isopleths for growing degree days are calculated from U.S. Geological Survey (1965) and from program DATGEN (Appendix A-T) ................. 5

3 Flow diagram of the FORAR model . . . . . . . . . 8

4 Functional form for the random death process. The model. assumes that $1 \%$ of all the seedlings of a species will live to reach the maximum known age. In the example shown, the maximum age of loblolly pine is 350 years . . . 10

5 Functional form for the optimum growth equation. The slope of the curve is a function of AGEMX. The height of the curve is a function of the maximum dbh recorded for the species (Pardo 1973) ............ 14

6 Functional form relating available light AL to photosynthetic rate $r(A L)$. Equations are from Kramer and Kozlowski (1960)................. 15

7 Functional form relating degree-days DEGD to the effect of climate on the growth of a tree species. In this example, sassafras can not grow if the degree-days are less than 3686 or greater than 10947 . . . . . . . . . 16

8 Linear function relating basal area on the $1 / 12$ ha plot. (BAR) to a general competition factor $S(B A R)$. The maximum basal area the plot can maintain is from Dick Williams (personal communication 1975) . . . . . 18 


\section{INTRODUCTION}

Because of the relative ease of estimating the necessary input parameters and because the model retains information on both individuals and species, FORAR (FORest in ARkansas stand simulation model) is versatile enough to be used in several different types of ecological studies. Changes in species composition through succession or because of long-term perturbations can be examined and consequences of different timber and wildlife habitat management techniques can be predicted. Changes in tree species abundance (e.g. to dominance or extinction) can be determined. The model provides dynamic simulations of what is classically referred to as the structure and function of ecosystems. The usefulness of different measures of such indices as diversity, productivity, or stability can be studied.

This user's manual describes the FORAR model, which simulates an upland forest of Union County in southcentral Arkansas. The mode? was developed from FORET (Shugart and West 1977), a modified version of the JABOWA model used by Botkin et al. (1972a, 1972b). The logging subroutine has been expanded in FORAR. A subroutine to burn the plot and probabilities of trees dying from fire damage has been added. Soil competition is computed using basal area instead of biomass. A fifth environmental variable, species-specific epidemics, has been added to subroutine BIRTH to affect seedling establishment. In addition, variables have been added, deleted, renamed, or shifted to other subroutines to make the program more efficient.

FORAR simulates composition and growth of a forest stand on the basis of each tree greater than $1.27 \mathrm{~cm}$ in diameter at breast height $(\mathrm{dbh})$ on a $1 / 12$ ha circular plot. The model computes (1) the numbers and hinmass of each species and (2) the dbh, age, and species of each individual tree. Once a year, trees are stochastically kllled ur deter. ministically grown and new trees are stochastically planted. Individual trees are killed by a probability function that is scaled according to the maximum age recorded for the appropriate species. The probability that a specific tree will die during a given simulated year 15 increased if its growth rate (expressed as diameter increment) falls below an acceptable minimum $(0.1 \mathrm{~cm} / \mathrm{yr})$. Stocking of new seedlings and sprouts in a given simulated year depends on the computed leaf-area index of the plot and the condition of five environmental variables discussed below. The tree species to be stocked are chosen randomly from those species which can germinate under the existing conditions for soil, temperature, wildlife populations, and epidemics. Trees grow according to a species-specific optimum growth function that is modified by soil moisture, competition, available light, and climate. The optimum growth function for each species is a function of the maximum known age, the maximum $\mathrm{dbh}$ and the maximum height recorded for the species. The driving variable for the model is degree-days, which is randomly chosen at the beginning of each year from a normal distribution with appropriate mean and variance. FORAR is written in FORTRAN IV and 
has been implemented on IBM 360 series computers. The present version of the model considers up to 35 tree species and up to 700 individual trees and can simulate the forest for any prespecified number of years.

\section{PROGRAM DESCRIPTION}

The deck setup of FORAR is shown in Figure 1. The control cards shown are those necessary to run the program on the ORNL IBM 360/91 computer. The program is listed in Appendix A-3. In a typical run the maximum computer core used is 270K. Computer time needed will depend on the size of the run, i.e., how many different plots are wanted, how many species are used, and how many years each plot is run. A run of three plots, each potentially having 33 species and running for 600 years, takes approximately two minutes of CPU time.

\section{INPUT}

The program currently reads in parameter values for each tree species using the format:

$6 A 4, F 6.0, F 5.0, F 4.3, F 5.2, I 1, F 4.0, F 2.0, F 5.1, F 2.0, F 4.1, F 4.0,5 L 1, I 4, F 3.1$.

This format can easily be changed in subroutine DATA to suit the user. Table 1 lists and describes the input variable names in the order in which they are entered in the above format. Most of the parameters, such as shade tolerance or maximum age, are relatively straight-forward and can be derived from standard textbooks of dendrology or silvics. Harlow and Harrar (1969) and Fowells (1965) were used in the present case for such parameter estimations.

DMAX and DMIN are the maximum and minimum degree-day values associated with the geographic range of each species. They are calculated (using a sine wave, see Appendix A-1) from the January and July mean temperatures at the northern and southern ends of the range of each species (e.g., Figure 2). B2 and B3 are the coefficients of the following equation relating height to diameter (in $\mathrm{cm}$ ):

$$
H=137+B 2 D-B 3 D^{2} \text {. }
$$
Solving for $B 2$ and $B 3$, using $H=H_{\max }$ and $\frac{d H}{d D}=0$ when $D=D_{\max }$ Botkin et
a1. 1972a) results in: 


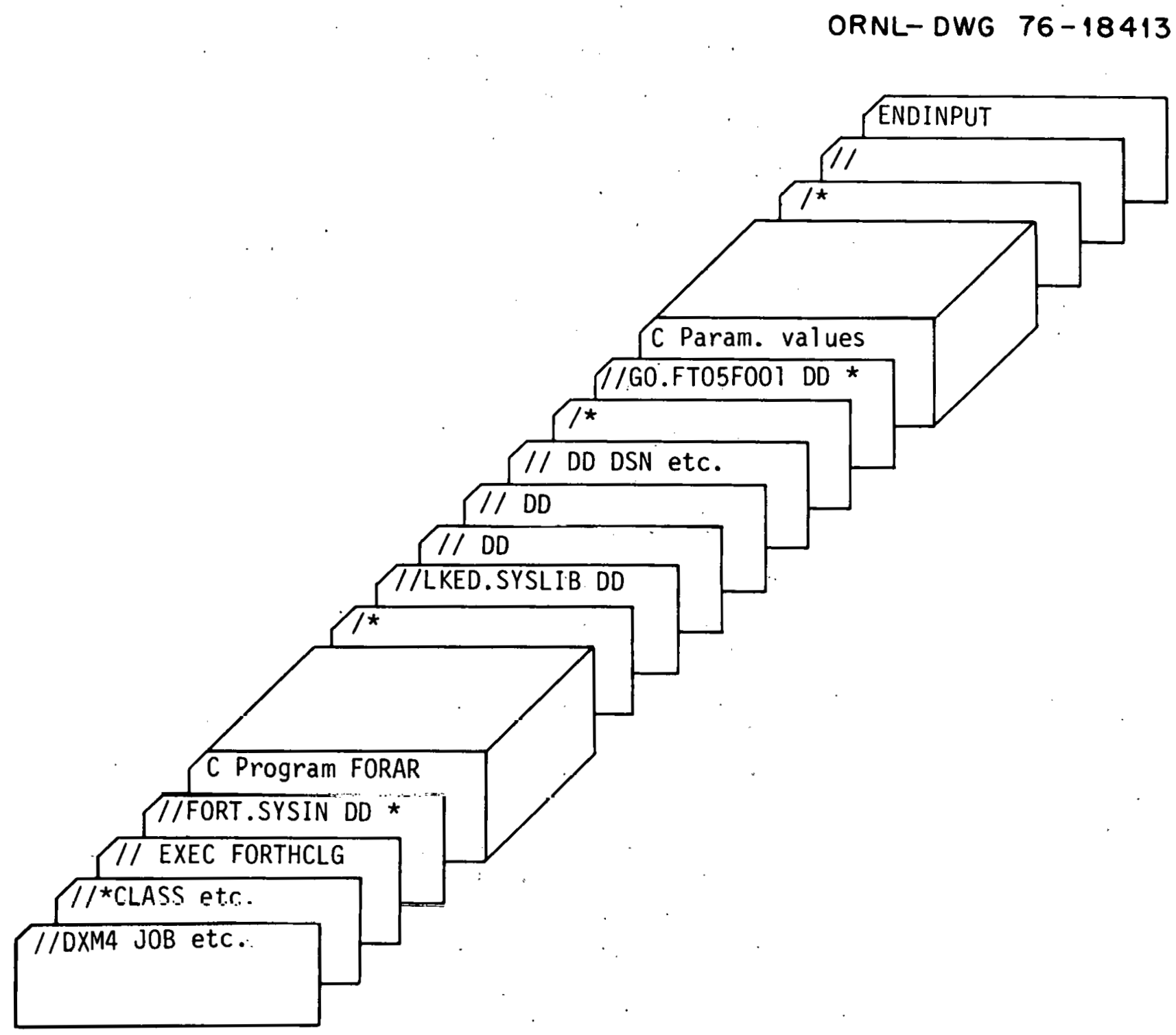

Fig. 1. Deck structure and job setup for program FORAR. 
Table 1. Parameters used in the FORAR model.' Table 2 lists the values used for each tree species. See text for explanation of variables.

\begin{tabular}{|c|c|c|}
\hline Parameter Name & Meaning & Field \\
\hline AAA & Scientific name (up to 24 letters) & $x x x x x x x x x x x x x x x x x x x x x x x x x x x$ \\
\hline DMAX & $\begin{array}{l}\text { Maximum degree-days for species } \\
\text { range } \\
\text { see text) }\end{array}$ & $x x x x x$. \\
\hline DMIN & $\begin{array}{l}\text { Minimum degree-days for species } \\
\text { range }(\text { see text) }\end{array}$ & $x x x x$. \\
\hline B3 & Derived gröwth parameter (see text) &.$x x x$ \\
\hline B2 & Derived growth parameter (see text) & $x x: x x$ \\
\hline ITYPE & $\begin{array}{l}\text { Shade tolerance } \\
\begin{aligned} 1 & =\text { tol erant } \\
3 & =\text { intolerant }\end{aligned}\end{array}$ & $x$ \\
\hline AGEMX & Maximum age recorded for the species & $x x x$. \\
\hline C & $\begin{array}{l}\text { leaf area constant } \\
\begin{array}{l}1=\text { deciduous } \\
2=\text { coniferous }\end{array}\end{array}$ & $x$ \\
\hline G & Derived Growth constant (see text) & $x x x \cdot x$ \\
\hline STEND & $\begin{array}{l}\text { Tendency to sprout } \\
\text { Value of } 0 ., 1 ., 2 \text {, or } 3 \text {. }\end{array}$ & $x$. \\
\hline SPTMIN & $\begin{array}{l}\text { The minimum dbh of a tree that will } \\
\text { sprout }\end{array}$ & $x x \cdot x$ \\
\hline SPTMAX & $\begin{array}{l}\text { The maximum dhh of a tree that will } \\
\text { sprnut. }\end{array}$ & $x \times x$. \\
\hline$s(1)$ & $\begin{array}{l}\text { Must the seed liave d l1tter layer to } \\
\text { germinate? value of } T \text { of } F\end{array}$ & $x$ \\
\hline$s(2)$ & $\begin{array}{l}\text { Must the seed have mineral soil to } \\
\text { jeminiinid lu? valuc of } T \text { or } 1\end{array}$ & $x$ \\
\hline$\varsigma(3)$ & $\begin{array}{l}\text { Is the seedling suscepllble to hot } \\
\text { years? value of } T \text { or } F\end{array}$ & $x$ \\
\hline$s(4)$ & $\begin{array}{l}\text { Is the seedling a highly-preferred } \\
\text { roud fur wildlifc? value of } T \text { or } F\end{array}$ & $x$ \\
\hline$S(5)$ & $\begin{array}{l}\text { Is an epidemic seriousiy damaging the } \\
\text { species? value of } T \text { or } F\end{array}$ & $x$ \\
\hline KTIME & $\begin{array}{l}\text { Number of years after a bare plot that } \\
\text { species is liable to be present }\end{array}$ & $x x x$ \\
\hline SOIM & $\begin{array}{l}\text { The fraction of maximum recorded dbh th } \\
\text { species will attain on an upland site }\end{array}$ & he \\
\hline
\end{tabular}


ORNL DWG 76-18984

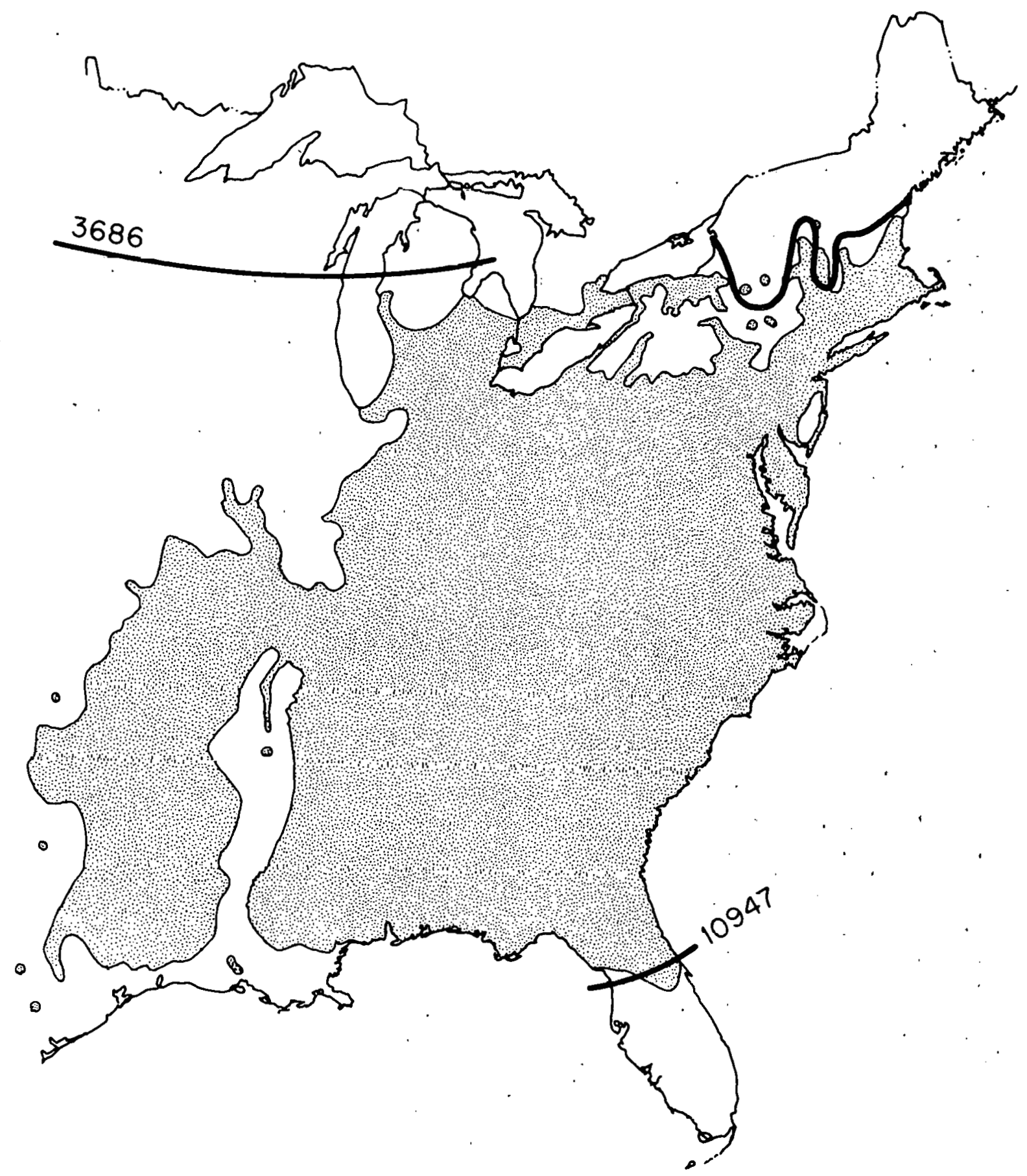

Fig. 2. Growing degree-day limits DMAX and DMIN for the geographic range of flowering dogwood (Cornus florida). Isopleths for growing degree days are calculated from U.S. Geological Survey (1965) and from program DATGEN (Appendix $A-1$ ). 


$$
B 2=\frac{2\left(H_{\max }-137\right)}{D_{\max }}, B 3=\frac{\left(H_{\max }-137\right)}{\left(D_{\max }\right)^{2}} \text {. }
$$

The growth constant $G$ is derived from Equation (4) below and the assumption that $2 / 3$ of the maximum $d b h$ of the tree is reached at $1 / 2$ the maximum age. G can be solved for directly (see Botkin et al. 1972b) or found by using a simple program of tree growth on an interactive computer (see Appendix A-2). The variable KTIME is an attempt to handle variation in seed source availability. If there is no parent tree on the plot and if the variable IMYR (the number of years that have passed since the plot had no trees and mineral soil) is greater than KTIME, then it is assumed there is no seed source for the species and that it can not be established by seeding. The input values used in the present version of FORAR are listed in Table 2.

The model usually starts a plot with no trees; however, subroutine LOAD can be used to input any desired initial conditions. If a litter layer is wanted at the beginning of a plot, IMYR should be given an initial value greater than 15 .

\section{Subroutines}

The flowchart for FÜRAR is shown in Figure 3 . There are 14 subroutines in addition to the main program; however, KILL, BIRTH, and GROW are the main elements in terms of actual computation.

Whenever a random number is needed for any model computation, a call to subroutine RANDOM returns a random number drawn from a flat distribution between 0 and 1 . In subroutine DATA the user declares the number of plots wanted, the number of tree species, the number of years each plot will be run, the interval of time between successive outputs, the annual insolation, the maximum basal area a plot can attain, and the mean for DEGD. Subroutines PLOTIN and INIT initialize variables, and PLOTIN also updates and prints the plot number.

Subroutine GAUSS randomly chooses a value for DEGD - total degreedays for a year, based on a growing degree-day temperature of $42^{\circ} \mathrm{F}-$ from a normal distribution. The mean and standard deviation of DEGD can be calculated from data available from the National climatic Center, Asheville, North Carolina. 
Table 2. Parameter values used in the FORAR model. Scientific binomials follow Little (1971).

\begin{tabular}{|c|c|c|c|c|c|c|c|c|c|c|c|c|c|c|c|c|c|c|}
\hline Species & DMAX ${ }^{3}$ & OMIN $^{3}$ & B.3 & B2 & ITYPE & AGEMX & $c^{\theta}$ & G & STEND & SPTMIN & SPTMAX & & & $s$ & & & KTIME & solm \\
\hline 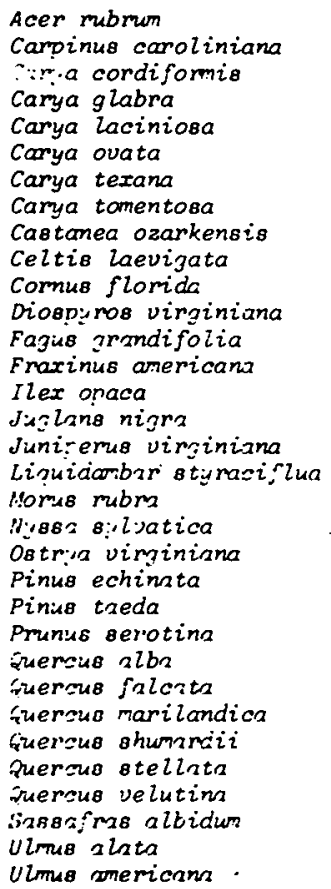 & $\begin{array}{r}13395 \\
10947 \\
9461 \\
12652 \\
8718 \\
12652 \\
9461 \\
10947 \\
7756 \\
12652 \\
10947 \\
13395 \\
10204 \\
10947 \\
10947 \\
8499 \\
10204 \\
10947 \\
13395 \\
12652 \\
10204 \\
9461 \\
10947 \\
10947 \\
10204 \\
10947 \\
10204 \\
10947 \\
10947 \\
9461 \\
10947 \\
10947 \\
12652\end{array}$ & $\begin{array}{l}1810 \\
2097 \\
3686 \\
3686 \\
5081 \\
4105 \\
5526 \\
3686 \\
5526 \\
5526 \\
3686 \\
5526 \\
2097 \\
2414 \\
5526 \\
3686 \\
2966 \\
5525 \\
3685 \\
3686 \\
1810 \\
5526 \\
6391 \\
3899 \\
2966 \\
5526 \\
5081 \\
5081 \\
5526 \\
3313 \\
3686 \\
5526 \\
1522\end{array}$ & $\begin{array}{l}0.173 \\
0.228 \\
0.336 \\
0.158 \\
0.318 \\
0.312 \\
0.318 \\
0.190 \\
0.085 \\
0.336 \\
0.536 \\
0.684 \\
0.151 \\
0 . C 80 \\
0.156 \\
0.674 \\
0.736 \\
0.191 \\
0.061 \\
0.202 \\
0.266 \\
0.290 \\
0.189 \\
0.083 \\
0.074 \\
0.078 \\
0.111 \\
0.199 \\
0.195 \\
0.097 \\
0.519 \\
0.230 \\
0.382\end{array}$ & $\begin{array}{l}52.58 \\
33.56 \\
69.21 \\
49.65 \\
72.46 \\
69.66 \\
57.56 \\
49.41 \\
21.72 \\
71.26 \\
40.81 \\
35.84 \\
46.20 \\
34.43 \\
42.61 \\
36.37 \\
57.75 \\
55.20 \\
22.15 \\
37.00 \\
49.50 \\
70.75 \\
60.81 \\
35.57 \\
36.37 \\
33.57 \\
24.86 \\
65.19 \\
47.75 \\
41.57 \\
75.51 \\
51.81 \\
39.35\end{array}$ & $\begin{array}{l}1^{8} \\
12 \\
31 \\
11 \\
11 \\
11 \\
1 \\
31 \\
1 \\
11 \\
11 \\
11 \\
11 \\
31 \\
12 \\
31 \\
31 \\
31 \\
14 \\
15 \\
17 \\
31 \\
31 \\
32 \\
11 \\
16 \\
35 \\
32 \\
31 \\
12 \\
32 \\
31 \\
3\end{array}$ & $\begin{array}{l}150^{2} \\
100 \\
300^{8} \\
300^{8} \\
300 \\
300^{2} \\
300 \\
300^{8} \\
60 \\
350 \\
100^{8} \\
150^{8} \\
400^{2} \\
300^{8} \\
200^{2} \\
250 \\
300^{1} \\
300^{2} \\
75^{5} \\
300^{8} \\
100 \\
300 \\
350^{2} \\
250^{1} \\
400^{9} \\
400 \\
400 \\
400 \\
400 \\
200^{9} \\
200^{8} \\
125^{5} \\
300^{1}\end{array}$ & $\begin{array}{l}1 \\
1 \\
1 \\
1 \\
1 \\
1 \\
1 \\
1 \\
1 \\
1 \\
1 \\
1 \\
1 \\
1 \\
1 \\
1 \\
2 \\
1 \\
1 \\
1 \\
1 \\
2 \\
2 \\
1 \\
1 \\
1 \\
1 \\
1 \\
1 \\
1 \\
1 \\
1 \\
1\end{array}$ & $\begin{array}{r}240.2 \\
129.9 \\
117.2 \\
111.3 \\
123.2 \\
116.5 \\
79.6 \\
98.6 \\
250.9 \\
112.7 \\
88.7 \\
234.1 \\
80.7 \\
113.3 \\
133.5 \\
161.5 \\
107.1 \\
119.4 \\
260.6 \\
54.8 \\
219.1 \\
128.4 \\
174.6 \\
139.5 \\
100.7 \\
82.9 \\
36.3 \\
115.9 \\
67.9 \\
100.1 \\
108.1 \\
212.5 \\
141.8\end{array}$ & $\begin{array}{l}2^{1} \\
2 \\
2^{5} \\
2^{5} \\
2^{5} \\
2^{5} \\
2^{5} \\
2^{5} \\
212 \\
21 \\
31 \\
21 \\
21 \\
21 \\
15 \\
11 \\
01 \\
21 \\
0^{5} \\
11 \\
1 \\
21 \\
01 \\
21 \\
21 \\
21 \\
2 \\
21 \\
21 \\
21 \\
31 \\
1 \\
11\end{array}$ & $\begin{array}{c}12.0^{8} \\
6.0^{8} \\
12.0^{8} \\
12.0^{8} \\
12.0 \\
2.0^{1} \\
12.0^{2} \\
12.0^{2} \\
12.0^{2} \\
6.0^{1} \\
12.0^{1} \\
12.0^{8} \\
6.0^{8} \\
6.0^{1} \\
6.0 \\
6.0^{1} \\
12.0^{1} \\
12.0^{1} \\
12.0^{1} \\
60.0^{1} \\
6.0^{1} \\
6.0^{1} \\
12.0^{1} \\
6.0^{1} \\
12.0^{1} \\
12.0^{1} \\
12.0^{1} \\
12.0^{1} \\
12.0^{1} \\
12.0^{1}\end{array}$ & $\begin{array}{c}150^{11} \\
70^{11} \\
110^{11} \\
145^{11} \\
90^{11} \\
110^{11} \\
110^{11} \\
130^{11} \\
12511 \\
11511 \\
3511 \\
210^{8} \\
30^{8} \\
20 \\
35^{11} \\
40 \\
120^{11} \\
80^{1} \\
180^{11} \\
90^{1} \\
90 \\
2011 \\
160^{11} \\
210^{1} \\
40^{1} \\
30^{1} \\
40 \\
160^{1} 1 \\
40^{1} \\
40^{1} \\
60^{1} \\
110 \\
240^{1}\end{array}$ & $\begin{array}{l}F^{1} \\
F \\
T 8 \\
T 1 \\
T \\
T^{8} \\
T \\
T^{1} \\
T \\
T \\
F 8 \\
F 1 \\
F 1 \\
F 1 \\
F 8 \\
T^{3} \\
F 1 \\
F 1 \\
T 5 \\
F 8 \\
F \\
F 1 \\
F 1 \\
F 1 \\
T 1 \\
T 8 \\
F 5 \\
F 1 \\
T 1 \\
F 1 \\
T 1 \\
F \\
F 1\end{array}$ & $\begin{array}{l}T^{1} \\
F \\
F^{2} \\
F^{2} \\
F \\
F^{2} \\
F \\
F^{2} \\
F \\
F \\
F^{1} \\
F^{2} \\
F^{2} \\
T^{2} \\
F^{2} \\
F^{2} \\
T^{1} \\
F^{1} \\
F^{5} \\
T^{8} \\
F \\
T^{1} \\
T^{1} \\
T^{1} \\
F^{1} \\
F^{8} \\
F \\
F^{1} \\
F^{1} \\
T^{1} \\
F^{1} \\
F^{5} \\
F^{1}\end{array}$ & $\begin{array}{l}T \\
F \\
T^{8} \\
T^{8} \\
T \\
T 8 \\
T \\
T^{8} \\
T \\
F \\
T^{1} \\
T^{8} \\
T^{8} \\
T^{8} \\
F \\
T^{8} \\
F^{8} \\
F^{1} \\
T \\
F^{8} \\
F \\
F^{1} \\
F^{1} \\
F^{8} \\
F^{1} \\
F^{8} \\
F \\
F \\
F^{8} \\
F^{8} \\
F^{8} \\
F \\
T^{1}\end{array}$ & 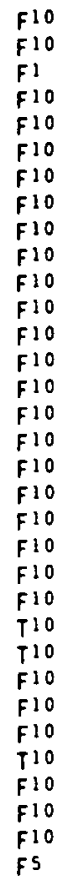 & 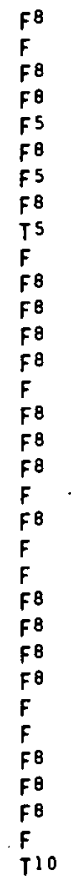 & $\begin{array}{c}9999 \\
9999 \\
30 \\
30 \\
9999 \\
9999 \\
9999 \\
9999 \\
9999 \\
9999 \\
9999 \\
305 \\
9999 \\
9999 \\
9999 \\
205 \\
205 \\
9999 \\
305 \\
9999 \\
9999 \\
9999 \\
9999 \\
9999 \\
9999 \\
9999 \\
9999 \\
305 \\
9999 \\
9999 \\
205 \\
9999 \\
9999\end{array}$ & $\begin{array}{l}0.5 \\
0.4 \\
0.8 \\
0.5 \\
0.4 \\
0.7 \\
0.5 \\
0.8 \\
0.8 \\
0.6 \\
0.9 \\
0.3 \\
0.5 \\
0.9 \\
0.5 \\
0.7 \\
0.9 \\
0.7 \\
0.3 \\
0.7 \\
0.4 \\
1.0 \\
1.0 \\
0.7 \\
0.8 \\
0.9 \\
1.0 \\
0.7 \\
1.0 \\
0.8 \\
0.8 \\
0.4 \\
0.4\end{array}$ \\
\hline
\end{tabular}

' From Fowells (1965)

2From Harlow and Harrar (1969)

${ }^{3}$ From Little (1971) and U.S. Geological Survey (1965)

SFrom Higginton (1964)

GFrom Baker (1949)

From Peattie (1950)

OFrom Shugart and West (1977)

'From Northeastern Forest Experiment Station (1971)

IOFrom Martín et al. (1971)

12 From Moore 1960$\}$

13 All other values not othentse referenced were developed duririg the course of this project. 


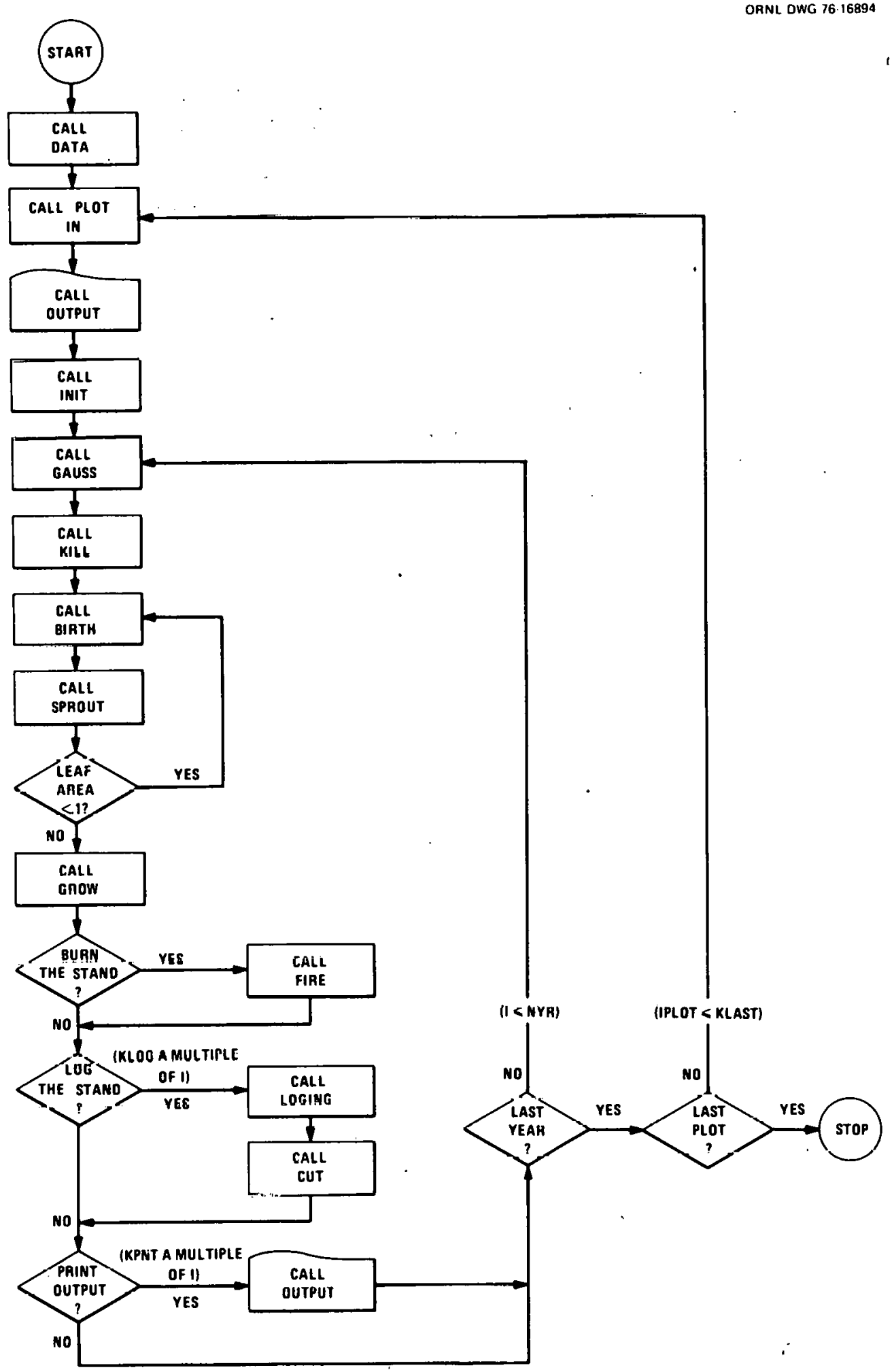

Fig. 3. Flow diagram of the FORAR model. 
Subroutine KILL

FORAR, like the Botkin model, assumes that individual tree death can be viewed as a stochastic process, rather than delineating all the different and complex causes of mortality. The probability that a tree will be killed in any one year is $p=1-(1-\varepsilon)^{n}$ (Botkin et al. 1972b). The model assumes that $1 \%$ of all seedlings of a species will live to reach the maximum age for that species (Figure 4). Setting $p$ equal to 0.99 and $n$ equal to AGEMX (the maximum known age a species can attain) results in:

$$
\varepsilon=4.605 / \text { AGEMX . }
$$

Once a year KILL generates a random number for every tree, and the tree is killed if the random number generated is less than $\varepsilon$.

In the present version of FORAR, there are two cases in which the kill probabilities of a tree are changed from the above statement. First, the model uses the array NOGRO to keep track of those trees that grow less than $0.1 \mathrm{~cm}$ dbh per year. A tree has only one chance in a hundred of surviving 10 years if such a growth rate is maintained (Botkin et al. 1972b). Accordingly, the random number generated has to be less than 0.368 to kill such a tree. Secondly, a moderate fire (described below) will "damage" those species that are susceptible to fire. In the present version of FORAR, a susceptible tree that is present on the plot when a moderate fire occurs is given a $20 \%$ chance of living 5 years (J. Warren Ranney, personal communication 1976); thus, the random number generated must be less than 0.275 to $k i 17$ the tree.

Trees are also killed deterministically if there is logginy or a fire. To log the circular plot, the user specifics in subroutine LOGING the upper and lower diameter limits of each species of the trees to be logged. Subroutine CIIT then removes all trees on the plot within these diameter limits. In subroutine FIRE the user has a choice of specifying a light, a moderate, or a severe burn. A light fire sets the logging limits of each species to a minimum of $0 \mathrm{~cm}$ and a maximum of $12.7 \mathrm{~cm}$ and then calls subroutine CUT to remove the trees. A severe fire removes all trees from the plot and resets the bare plot counter IMYR to zero, allowing the pioneer species with small values of KTIME to reenter the plot. A moderate fire uses subroutine CUT in the same way as a light burn to remove all the trees of species that are extremely susceptible to fire damage, a11 the trees less than $25.4 \mathrm{~cm} \mathrm{dbh}$ of species that are moderately susceptible to fire damage, and all the trees less than $17.8 \mathrm{~cm}$ dbh of resistant species. The susceptibility of each species to fire damage is established in the COMPUTED GO TO statements in subroutine FIRE. The values used in FORAR were taken from Davis (1959), Fowells (1965), Harlow and Harrar (1969), or developed in the course of this project. A moderate fire also resets IMYR 


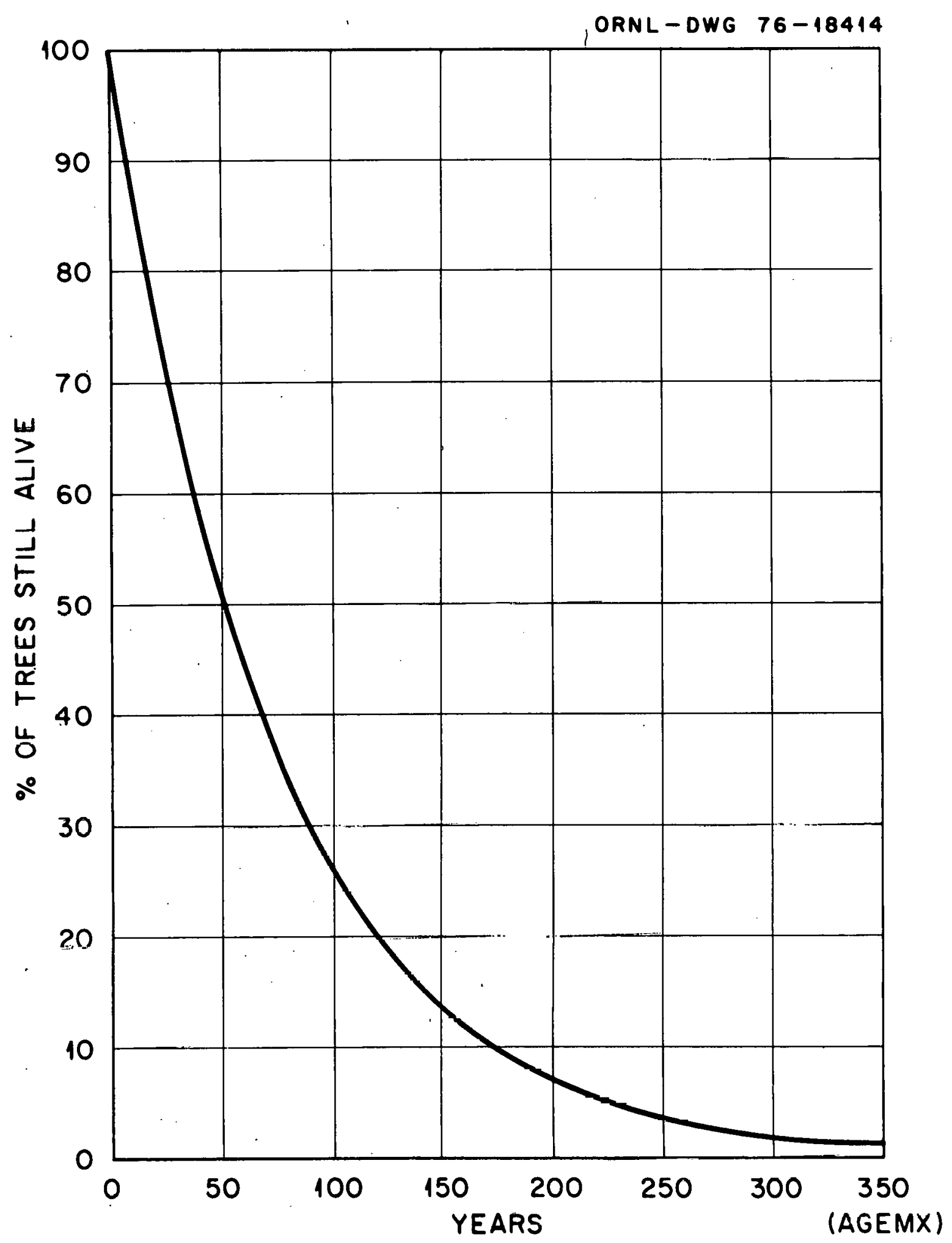

Fig. 4. Functional form for the random death process. The model assumes that $1 \%$ of all the seedlings of a species will live to reach the maximum known age. In the example shown, the maximum age of loblolly pine is 350 years. 
to zero and changes the survival probabilities of those damage-susceptible trees that were large enough to survive the fire, as discussed above.

\section{Subroutine BIRTH}

BIRTH calculates the biomass already on the plot and sets the correct values for the year for the five environmental variables corresponding to the $S$ array in Table 1 . As in the FORET model (Shugart and West 1977), the soil is considered to be mineral soil if the biomass on the plot is less than 0.2 metric ton/ha and if IMYR (an additional parameter in the FORAR model) is less than 15. The soil is considered to have a litter layer if the plot biomass is greater than 0.1 metric ton/ha. It is a hot year if DEGD has a value greater than its mean. Wildlife populations are randomly chosen half the time to be large enough to consume the entire seed source of a preferred food species. In the FORAR model, an epidemic is randomly present half the time to destroy the seedlings of certain host species.

BIRTH then separates out those species capable of germinating under existing environmental conditions. For instance, we assume that a species requiring a litter layer to germinate (i.e. $s(i)-$ .TRUE.) cannot be stocked when there is no litter layer on the ground (i.e. when the biomass on the plot is less than 0.1 metric ton/ha). From the subset of possible species, the program randomly chooses from one to three species to actually stock in a given year. A random number of seedlings between zero and eight are then "born" for each of the one to three species and randomly assigned a dbh around $1.27 \mathrm{~cm}$ (Tree seedlings are established $137 \mathrm{~cm}$ tall in the model in order to have a nonzèrô dbh.).

After the new seedlings are established, subroutine BIRTH calls subroutine SPROUT, which checks to see if any trees of a species capable of sprouting have died since the last year. If they have, and if their diameter was within the sprouting range of that species (SPTMIN $\leq \mathrm{dbh}<$ SPTMAX), a random number of sprouts between zero and three are random$1 y$ given dbh's around $0.1 \mathrm{~cm}$ and are added to the plot. Where a maximum of three species of seedlings can enter the plot in one pass through subroutine BIRTH, only one randomly chosen tree can sprout in one pass through subroutine SPROUT.

Subroutine BIRTH then calculates whether the biomass on the plot is less than 0.1 metric ton/ha. If it is, the program returns to the top of subroutine BIRTH to go through the process again. Before returning to MAIN, BIRTH updates the age of all the trees. 
The basic growth function used by FORAR, FORET (Shugart and West 1977), and JABOWA (Botkin et a1. 1972a, 1972b) is:

$$
\delta\left(D^{2} H\right)=R L A\left(1-\frac{D H}{D_{\max } H_{\max }}\right) \text {, }
$$

where

$$
\begin{aligned}
D & =d b h \\
H & =\text { height } \\
D_{\max } & =\text { maximum dbh recorded for the species (Pardo 1973), } \\
H_{\max } & =\text { maximum height recorded for the species, } \\
R & =\text { a constant, and } \\
L A & =\text { leaf area. }
\end{aligned}
$$

This equation considers the trunk of a tree to be a cylinder and assumes that the change in volume of a tree in one year is proportional to the amount of sunlight the leaves receive times a factor for maintenance of the volume of living tissue already present (Botkin et al. 1972b). The assumptions of the model are as follows (For more details, see Botkin et al. 1972b):

$\begin{array}{ll}H=137+B 2 D-B 3 D^{2}, \\ L A \text { a leaf weight } \\ \text { leaf weight }=C D^{2}, \\ \text { and } & G=R C \\ \text { where } \quad & C=\text { leaf area constant, } \\ & G=\text { a gruwlih constant. }\end{array}$

Using the above equations in Equation (4) to solve for $D$, the annual increment of growth, we find:

$$
\delta D=G D \frac{\left(1-\frac{D H}{D_{\max } H_{\max }}\right)}{274+3 B 2 D-4 B 3 D^{2}}
$$


This is the basic equation for optimum growth on a good site with no competitors. An example of this function for two species is shown in Figure 5 .

FORAR modifies the annual growth equation by factors for shading, climate, competition, and soil moisture. In order to modify growth according to the amount of light each tree is receiving, subroutine GROW calculates the amount each tree is shaded, in 0.1 meter increments, by those trees on the plot that are taller. This is done using the equation:

$$
A L=P H I e^{0.25 S L A} \text {, }
$$

where

$$
\begin{aligned}
A L & =\text { available light for a given tree, } \\
\text { PHI } & =\text { annual insolation (in appropriate units), and } \\
\text { SLA } & =\text { shading leaf area (Botkin et al. 1972a). }
\end{aligned}
$$

SLA is calculated using Equation (6) as the leaf biomass above a given height (Shugart and West 1977, Sollins et al. 1973). Kramer and Kozlowski (1960) give equations to relate $A L$ to $r(A L)$, the photosynthetic rate:

$$
\begin{gathered}
r(A L)=i-e^{-4.64(A L-0.05)} \text { for tolerant species, } \\
r(A I)=2.24\left(1-e^{-1.136(A L-0.08)}\right) \text { for intolerant species. }
\end{gathered}
$$

The factor $r(\mathrm{AL})$ is then used as the shading factor multiplying the growth equation. Figure $G$ shows $r(\mathrm{AL})$ as a function of Al. for tolerant and intolerant species.

FORAR assumes a parabolic functional form for the effect of climate upon tree growth, T(DEGD). Figure 7 shows the relationship between the range of the species and $T(D E G D)$. Optimum climatic effect occurs in the middie of the climatic range of the species. DEGD values at the range extremes reduce $T(D E G D)$, and thus the growth of the trees of that species, to near zero.

The crude competition factor in the model is simply:

$$
S(B A R)=1-B A R / S O I L Q,
$$


ORNL-DWG $76-18415$

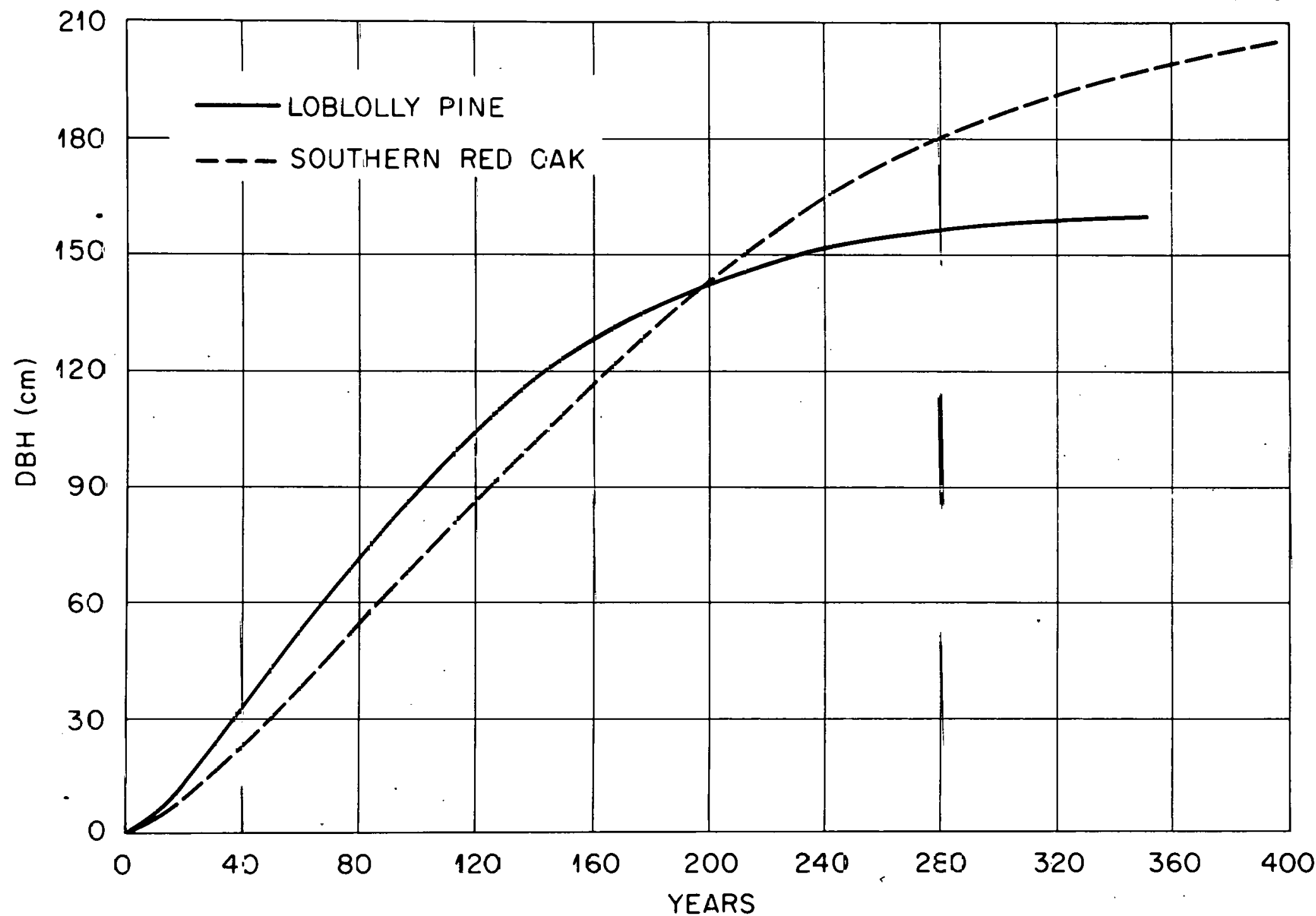

Fig. 5. Functional farm for the optimum growth equation. The slope of the curve is a function of AGEMX. The height of the curve is a function of the maximum dth recorded for the species (Pardo 1973). 


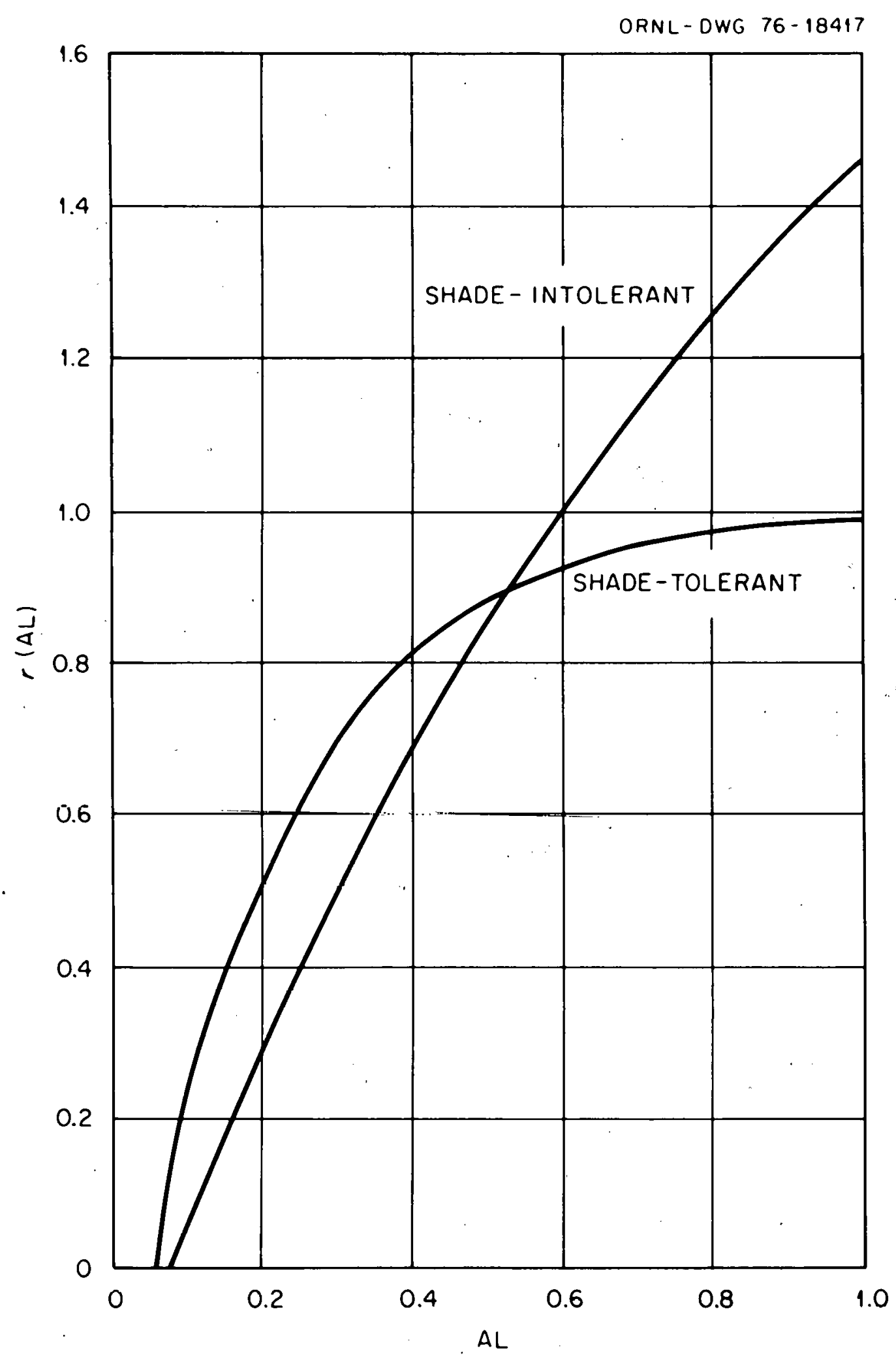

Fig. 6. Functional form relating available liaht AL to phutusynthetic rate $r(A L)$. Equations are from Kramer and Kozlowski (1960). 


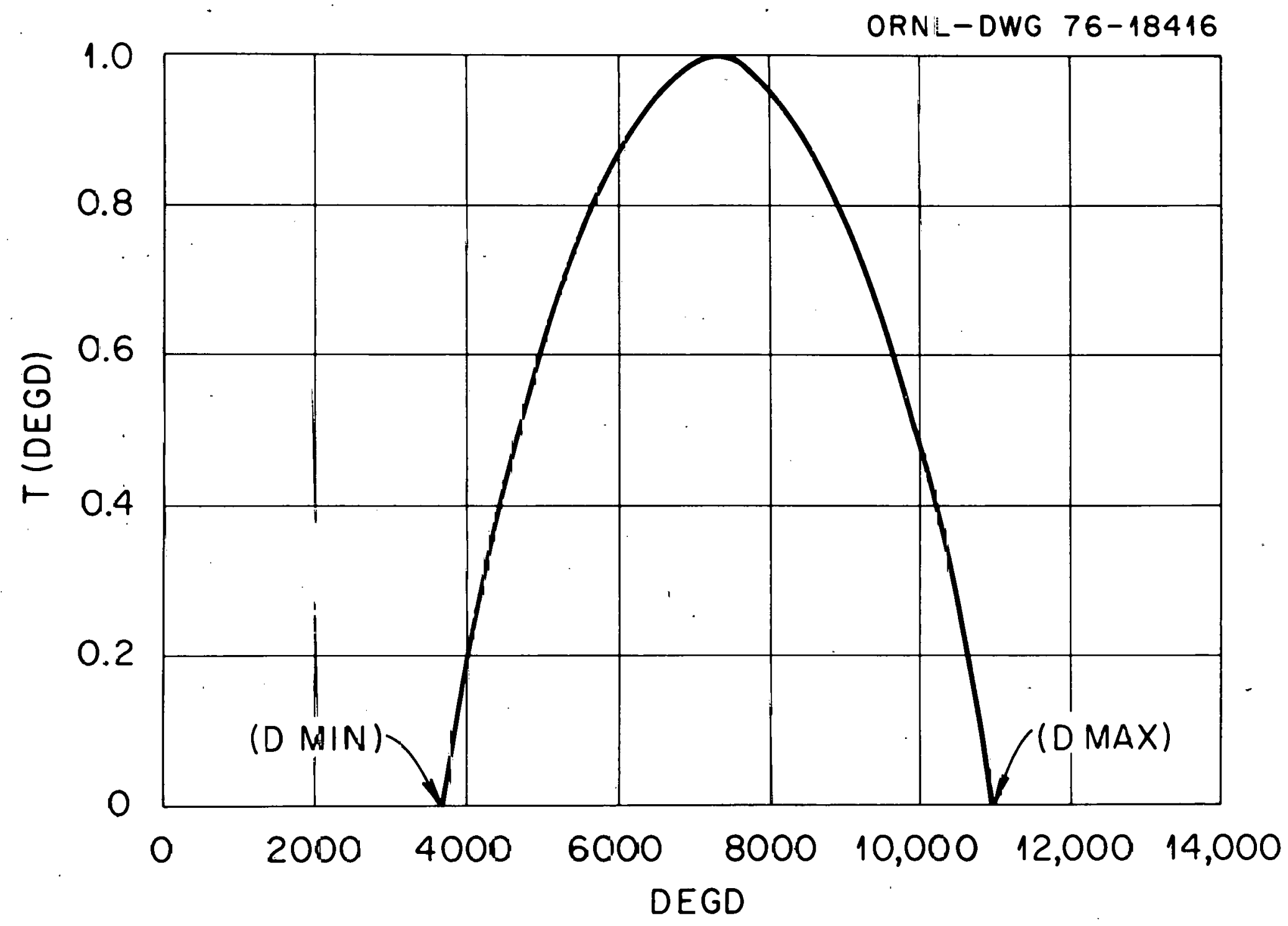

Fig. 7. Furictional fcrm relatirg degree-days DEGD to the effect of climate on the growth of a tree species. In this example, sasse-ras can not grow if the degree-days are less than 3686 of greater than 10947. 
where

$$
\begin{aligned}
S(B A R) & =\text { competition factor } \\
B A R & =\text { basal area on the plot, and } \\
\text { SOILO } & =\text { maximum basal area the plot can sustain. }
\end{aligned}
$$

A plot of $S(B A R)$ is shown in Figure 8 .

The last factor modifying tree growth, soil moisture, was added to FORAR when it was found that primarily-bottomland species were comprising too much biomass on the plot. For simplicity, SOIM was assumed to be a constant factor reducing (usually) the growth of a species on an upland site. A more realistic approach would be to use moisture as another driving variable of the model. This, however, would add another level of resolution to an already complex program. Species that are found primarily on dry, poor soils have values of SOIM near 1.0; whereas species that commonly grow well in bottomlands and grow much more poorly on upland sites may have values of SOIM around 0.5 .

The final growth equation for the model is thus:

$$
\delta D=G D \frac{1-\frac{D H}{D_{\max } H_{\max }}}{274+3 B 2 D-4 B 3 D^{2}} r(A L) T(D E G D) S(B A R) \text { SOIM. }
$$

\section{OUTPUT}

A sample output of FORAR is shown in Appendix A-4. Normal output of FORÁR shows, for each suecies, the number of trees on the plnt, their dbh's, and the biomass. Total biomass and leaf area on the plot are also given at the end of the species list. Output frequency (KPNT) is specified by the user in subroutine DATA. The model has an option to list all the trees that have died from random causes since the last printout, all the trees that have been removed by logging and the diameter limits for each species, and all the trees that have been killed by fire. 


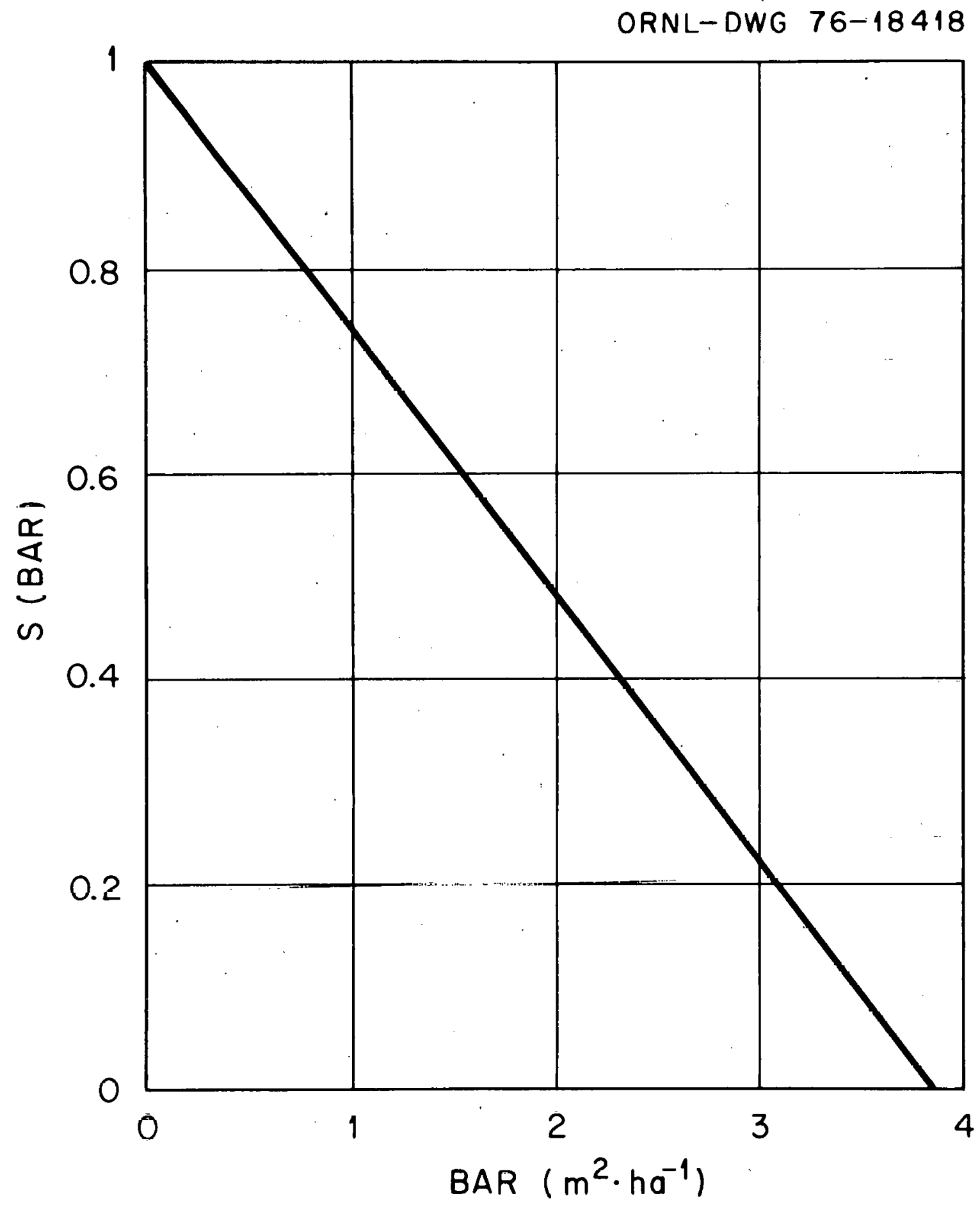

Fig. 8. Linear function relating basal area on the $1 / 12$ ha plot (BAR) to a general competition factor S(BAR). The maximum basal area the plot can maintain is from Dick Williams (personal communication 1975). 


\section{REFERENCES}

Baker, F. S. 1949. A revised tolerance table. J. Forestry 47:179-181.

Botkin, D. B., J. F. Janak, and J. R. Wallis. 1972a. A simulator for northeastern forest growth: a contribution of the Hubbard Brook ecosystem study and IBM research. IBM Research Report 3140.

Botkin, D. B., J. F. Janak, and J. R. Wallis. 1972b. Some ecological consequences of a computer model of forest growth. J. Ecology 60: 849-873.

Davis, K. P. 1959. Forest fire: control and use. McGraw-Hill Company, Inc. New York.

Fowells, H. A. 1965. Silvics of forest trees of the United States. USDA For. Ser. Hdbk. No. 271. 762 p.

Harlow, W. M., and E. S. Harrar. 1969. Textbook of dendrology. McGrawHill Book Company, New York.

Kramer, P. J., and T. Z. Kozlowski. 1960. Physiology of trees. McGrawHill Publishing Company, New York.

Little, E. L. 1971. Atlas of United States trees, Vol. I. Conifers and important hardwoods. U.S. Government Printing Office, Washington, D. C.

Martin, A. C., H. S. Zim, and A. L. Nelson. 1951. American wildlife and plants, a guide to wildlife food habits: the use of trees, shrubs, weeds, and herbs by hirds and mammals of the United States. Dover Publishing Company, Inc., New York.

Northeastern Forest Experiment Station. 1971. Oak symposium proceedings. 161 p. USDA Northeastern Forest Experiment Station, Upper Darby, Pennsylvania.

Pardo, R. 1973. AFA's social register of big trees. American Forests $79: 21-47$.

Peattie, D. C. 1950. A natural history of trees of eastern and central North America. Houghton Miffl in Company, Boston.

Shugart, H. H., and D. C. West. 1977. Development of an Appalachian deciduous forest succession model and its application to assessment of the impact of the chestnut blight. J. of Environ. Management 5. (in press) 
Sollins, P., D. E. Reichle, and J. S. 0lson. 1973. Organic matter budget and model for a southern Appalachian Liriodendron forest. EDFB/IBP-73/2. Oak Ridge National Laboratory, Oak Ridge, Tennessee.

U.S. Geological Survey. 1965. Monthly average temperatures for January and July. The National Atlas of the United States of America (1970). U.S. Government Printing Office, Washington, D. C.

Wigginton, B. E. 1965. Trees and shrubs for the Southeast. University of Georgia Press, Athens. 
Appendix A-1

Program DATGEN calculates annual degree-days from January and July mean temperatures. A sine function is used to estimate average daily temperature, with the minimum and maximum values equal to the January and July means, respectively. The area under the sine curve and above the $42^{\circ} \mathrm{F}$ line is then determined by integration and scaled to the proper value for degree-days.

In the listing shown, the degree-days are calculated and printed out for the matrix of January mean temperatures from $0^{\circ}$ to $70^{\circ}$ and July mean temperatures from $60^{\circ}$ to $90^{\circ}$. 


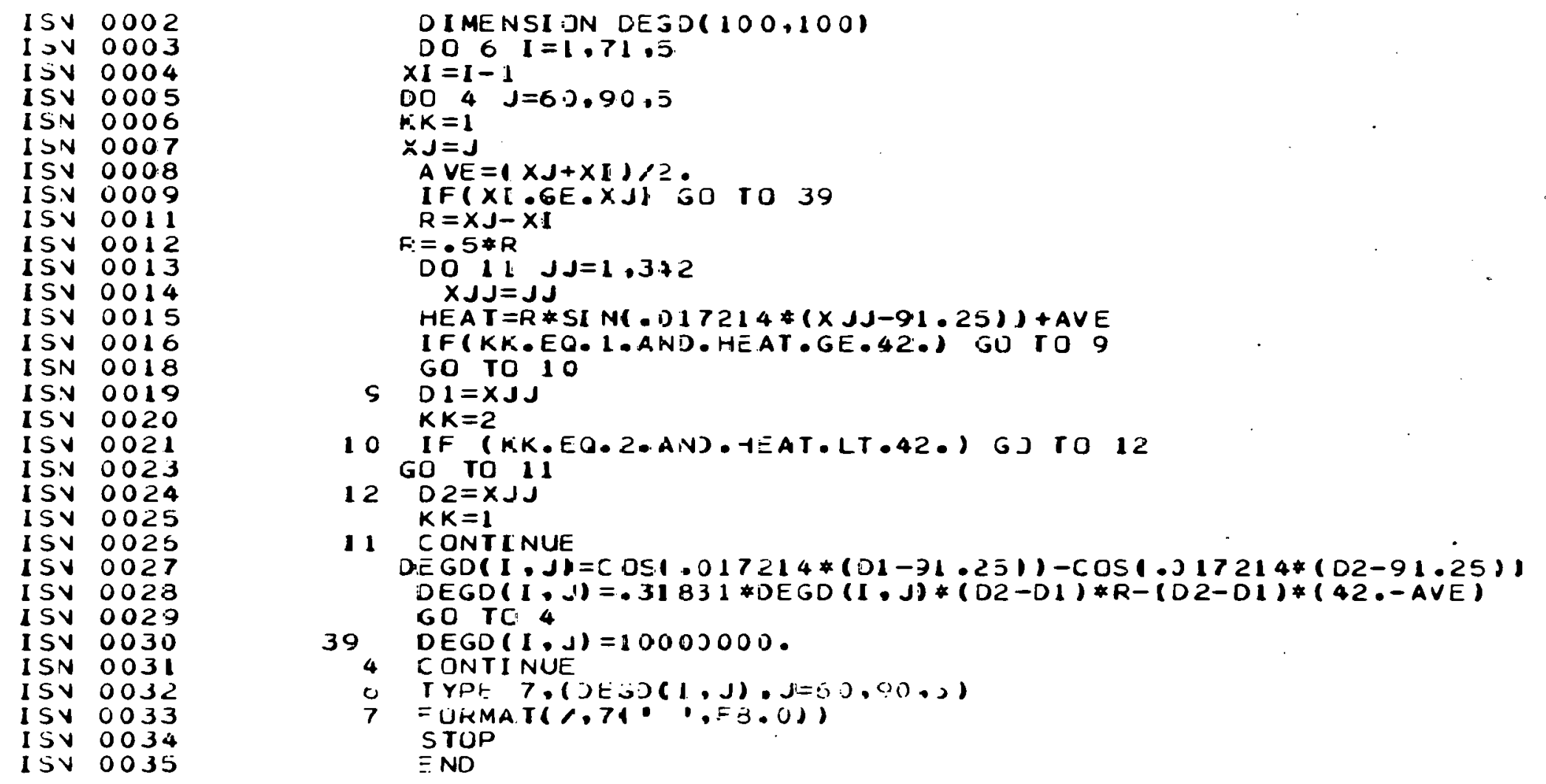


Appendix A-2

Program GFIX iteratively determines the value of $G$, the growth constant, for each tree species. $G$ is calculated using the optimum growth function developed by Botkin et al. (1972a, 1972b) and the assumption that a tree will attain $2 / 3$ of its maximum dbh at $1 / 2$ its maximum age:

$$
\delta D=G D \frac{\frac{D H}{1-D_{\max } H_{\max }}}{274+3 B 2 D-4 B 3 D^{2}}
$$

and

$$
D=2 / 3 D_{\max } \text { when } t=A G E M X / 2 \text {. }
$$

Any interactive computer system can be used to run this program. The values for DMAX, HMAX, B2, B3, and AGEMX for the species and the initial guess for $G$ are entered in. The value of $D B H$ typed out can then be compared to $2 / 3 D_{\max }$, and a better guess for $G$ can be entered for the next iteration. This is repeated until DBH becomes sufficiently close to $2 / 3$ D $\max$. 


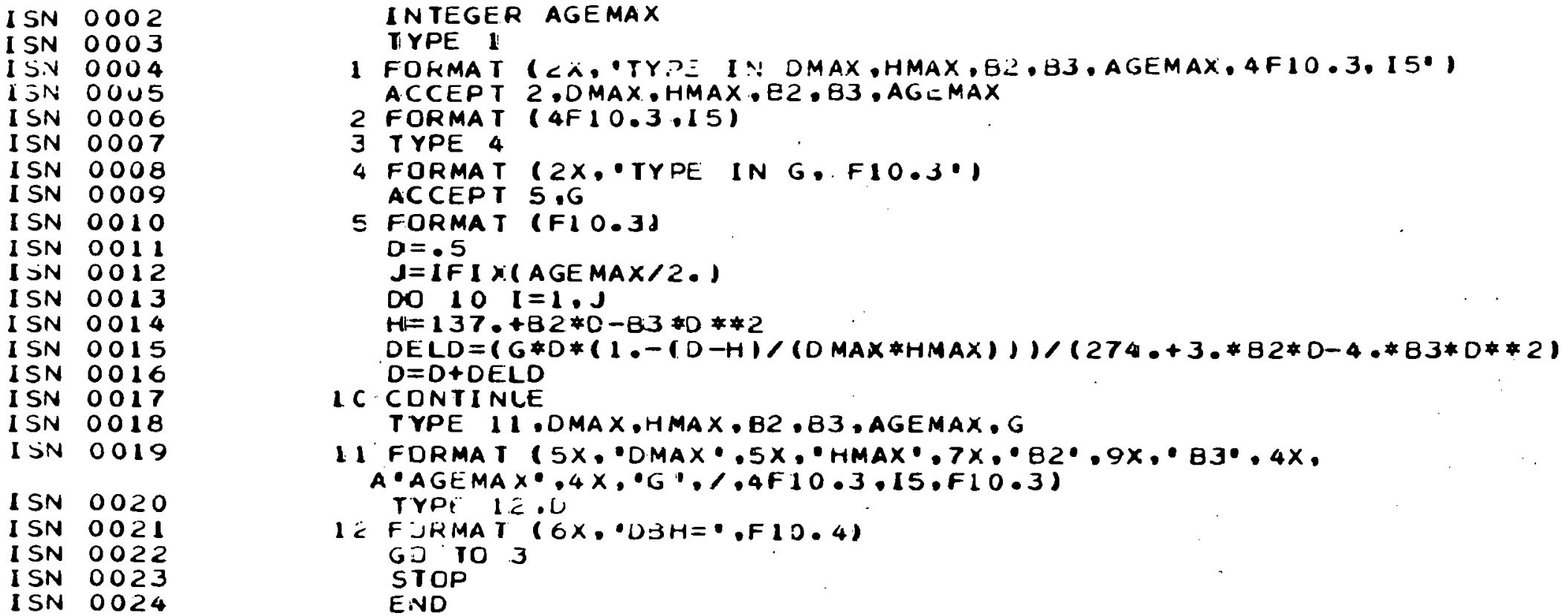


Appendix A-3

Listing of Program FORAR 


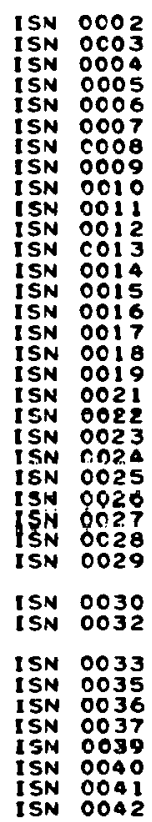

C STAND SIMUL ATOR MODIFIED FROM:

BOTKIN.0.B..J.F. JANAK.J.R. HALLIS 1970. A SIMULATOR FOR NORTHEASTERN ECOSYSTEM STLOY ANO IBM RESEARCH. RC 3140. IGM THOMAS J. WATSOM RE SEARCH CENTER, YORKTOWN HEIGHTS. NEW YORK, 21 . DIMENSION DBHITOO ' NTREES (35)

COMMON TFDATAK FAROAM(5OO) (3S) TI (35), BLIMIT(35). IMYR

COMMON TFOATAY FAROAM(SOOT. ALIMI

LOG ICAL SWITCH(S) S(35.5) . LOGS

DIMENSION RTIMET 3 ST

CH.KT IME - S

SWR

(35), B3(35). PH t SOILO.DEGO

CALL DATA

1 CONTINUE

CALL PLOTINCIPLOT .DBH, NTREESI

I MYR $=0$

I $N Y R=0$

CALL OUTPUT ( DEH. NTREESI

DO 9 J

$\boldsymbol{J} \boldsymbol{J}=\mathbf{J}$

IF IJJ.GT, II PRINT I3.IX

3 FORMAT

CALL INITIOBH.NTREES .OBHK. NTREEK, JUI

OO I I $=1$ : NYR

INYRE $=1$

CAL.T. FAUSSI $\mathrm{t} \times .700 .0 .8700 .0 .0 E 00)$

CALL KILL D DOH, NTREES I I Y I

CALL BIRTHIIX.NTREES

c

CALL GROW(DBH ONTREES)

IF (R.LT. .048) CALL FIRE (DBH.NTREES)

CALL LOGING (LOGSI

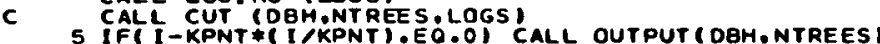

CONTINUE

IF(IPLOT EEO. KLAST, GO TO 99

gu ra 11

99 CONTINUE

STOP
END

SUBROUTINE LOADIDBH.NTREESI

OIMENSION DEH(TOO),NT REES (25)

COMMON TIRUN' INUEX

DO 1 IEI I NOE

RTAEESTIII=0.

RE TURN

10 continue

LOGS=.TRUE.

QFinition 


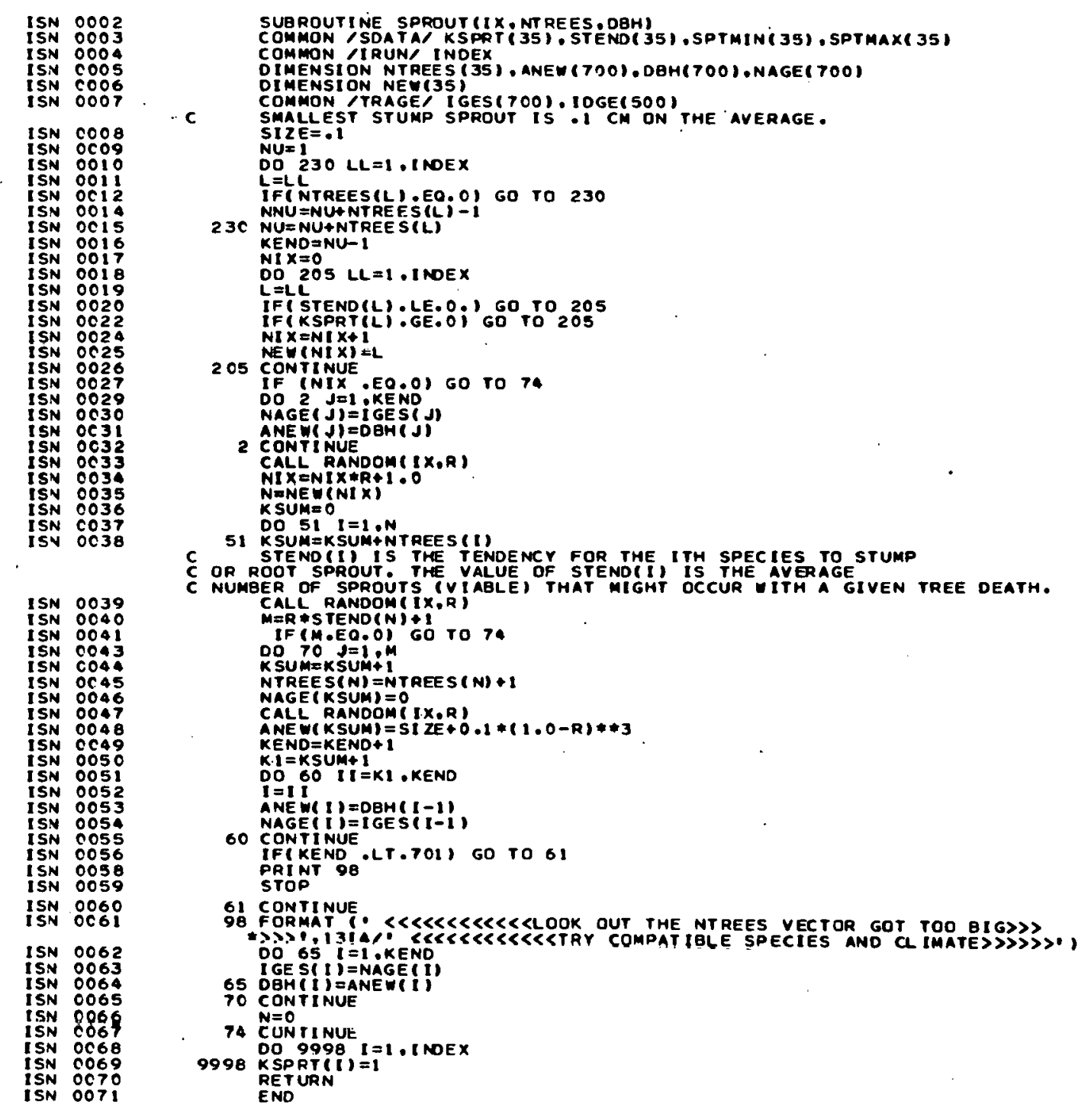




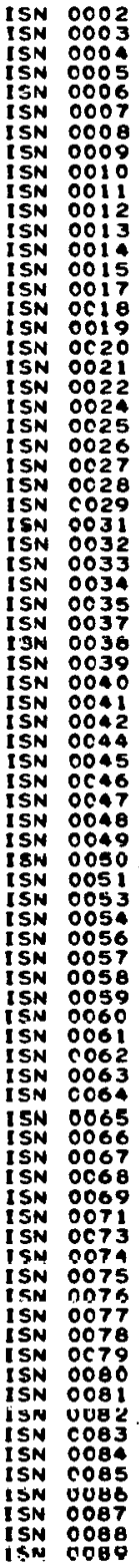

SUBROUTINE CUTIOBH,NTREES, LOGSI DIMENSION DBH(TOO), NTREES (35), ANEW(100)

COMMON PFOATAY FAROAM(500). ALIMIT(35) B BL IMIT(35), IMYA

(100) ikKaGe(100) COMMON 'SOATA, KSPRTi35). STENO(35). SPTMINi35). SPTMAX(35)

COMMON JIRUN/ INOEX

COMMON ATITLE, AAAl35.6)

LOG ICAL

OO I I I I I NDEX

NTOT=NTOT $\rightarrow$ NTEES (I)

1 CONTINUE

IF (NTOT.EO.O) RETURN

CUTT=.FALSE.

NE $=0$

$K B E G=1$

IF (.NOT-LOGSI GO TO 18

PRI NiT 15

15 FORMAT (12X. ODIAMETER LIMITS FOR LOGGING. BY SPECIES०

PRINT $14,(J, A L I M I T(J), 0 L I M I T(J), J=1$, INDEX)

14 FORMAT $(12 x, 15,2(2 x, F 5.1))$

8 OO 2 I I I I INDEX

CUTSP=OFALSE:

KEND=KEND +NTREES

Jif

IF (DBH(J).LT.ALIMITII).OR.OBHIJ).GT.BLIMITIII) GO TO NTAEES(I)=NIREES(I-I

NFW $=N F W+1$

DQHCUT (NFW) $=$ DEM (

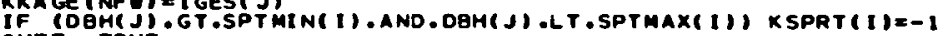

CUT SP=. TRUE

GOT TO 5

- NEW $=N E W+1$

ANE W(NEW) =DBH(J)

KAGES (NE DI

5 CONTINUE

IF (CUTSP.EO.C.FALSE. I) GO TO 72

If $=$ I MOT LOGS) GO TO 65

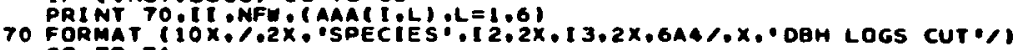

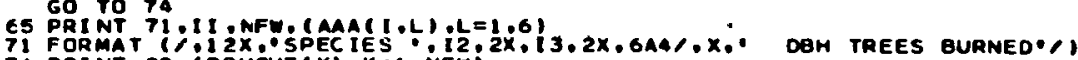

74 PRINT 29 , (DEACUT $(K), K=1$, NFWi

29 FORMAT (20X,AFB. 2 )

DO $B O K^{\prime}=1, N F$

60 CONTINUE

12 KBEG=KEND+

CONTINUE

IF (CUTT.EOD PFALSE I', GO TO 13

IF INEW.EO.OS GO TO 10

13 Go TO 8

SO FORMAT (5X.'NO TREES CUT?/I

Do 7 I-1 + Né

DBH (I)=ANE II

CONTINUE

RE TURN

10 SONTINUF

11 Format (10X./10X. 'ALL trees vere cut $/ 1$

oo $12 \mathrm{~s}=1.700$

Pвн J JIFO.

12 CONTINUE

RETUAN 


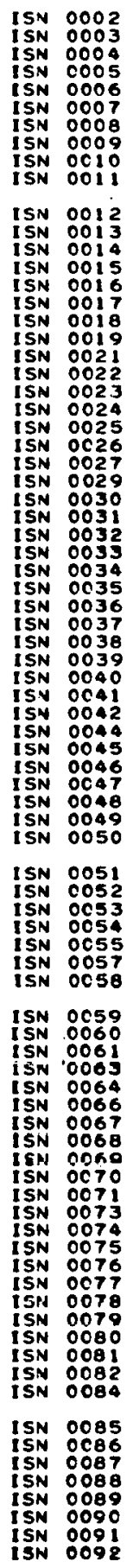

SUBROUTINE OUTPUT (OBH .NTREES)

DIMENSTON DBH(TOO). BDH(500). NTREES (35).10M(500), BAR(35)

COMMON KILO NOGRO(100), DOBH(500). KDEAD(35). AREA. KD

COMMON TRAGE, IGEST 700 ): IDGE(500)

COMMON IRUNNRE NYR,INYR.KPNT OKA GE.KTIMES, KLAST

COMMN

COMMON IIRUNY INDEX

11 FORMATIIN, YEAR SPEC. NUM.

MAME

B I OMA ZSS',

PRINT 21 ININY

21 FORMATIIS

96 NDE $A D=0$

NTO $T=0$

NDE AD =NDE AD $+K D E A D(1)$

1 NTOT=NTOT

IFINTOT.EQ.O) GO TO 100

$N=1$

$A R E A=0.0$

DO 20 II $I=1$, I NOEX

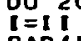

BAR(I) =0.0

IF(NTREES(I) . EO. O) GO TO 20

NN=N+NTREES $(i)-$ i

NI $=$ NTREES $(t)$

DO 50 JJ $=N, N N$

$j=J j$

50 ARE $A=A R E A+1.9283295 E-4 * D B H(J) * 2.129$

DO $97 \quad J=1, N$

$N 2=J+N-1$

$\operatorname{BDH}(J)=$ DeH ( N2)

97 CONTI NUE

(1)4.1193*DBH(N2)*2.393

TBAR = TBAR+BAR(I)

$N 2=M 1 N O(12, N 1)$

(I) $(A A A(I, K), K=1,6), B A R(1),(B D H(1), J=1 . N 2)$

P

5 FORMAT(20X, FB.3, $, 20 X, 4 F 8,3,1.20 X, 4 F B .3$ )

O CONTI NUE

TENAR =TBAR*.012

PRT 7 . NTOT OTBAR.AREA

7 FORMATCIOX/1OX.17.E12.3.' METRIC TON/HA. LEAF AREA =.,F 9.31

5 FORMATI $15 x \cdot 15$.

Go Tó 200

100 PRINT 3 IINYR

3 FORMATIIOX.'YEAR".IS." NO TREES LIVING")

THE IONDEO $=1810$. THEENDI GO TO 296

298 PRINT 297

297 FORMATIIOX,:NONE OF THE SPECIES YDU ARE USING CAN EXIST WITH TH is CLIMATE:I

STOP

296 THEEND $=13395$

IF (DEGD.GT. THEEND) GO TO 298

IFI NDEAD E E . O) RETURN

IF(NDEAO

201 FORMATU! DEAO TREES SINCE LAST PRINTOUT')

Do 99 IIII, NDEX

IFIKDEADII)

NI = KDEAD (I)

DO $98 \mathrm{~J}=1$. $N$

$N Z=J+N-$

BDH $(J)=D O B M(N 2)$

98 ConTINÜ

NS=MINOIT, $M I$

PRINT 4, I , KOEAOO (I), (BOH(J), IOM(J),J=1,N2

IF ( NI $:$ G T

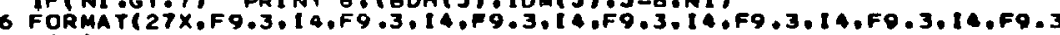

*Ial

FORMAT(5X,I5,17,10X,7(F9,3.14)1

N=N+KDEADII

99 CONTINUE

DO 299 I = I, I NDEX

299 CONTINUE

RETUAN

ENO 


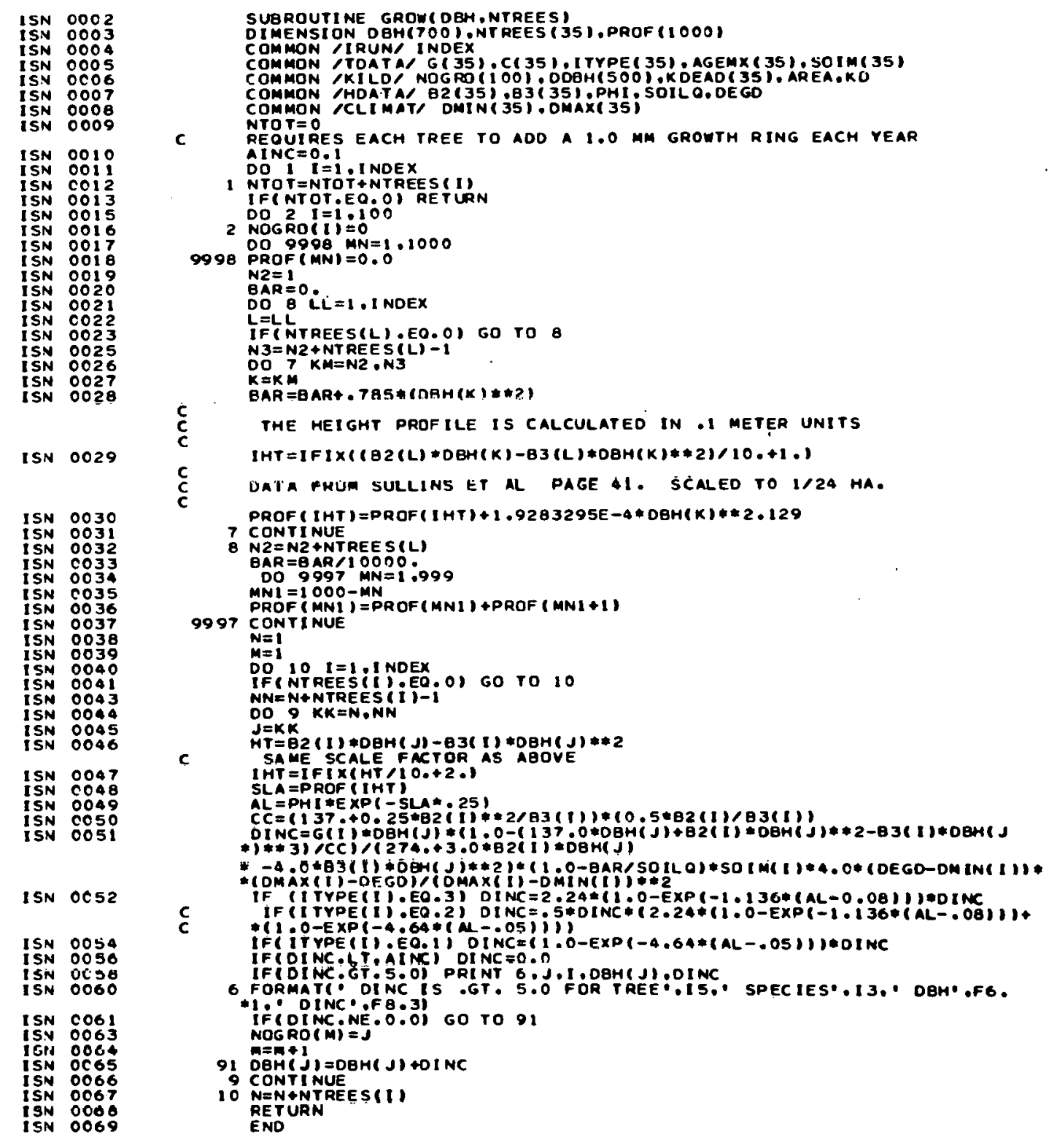




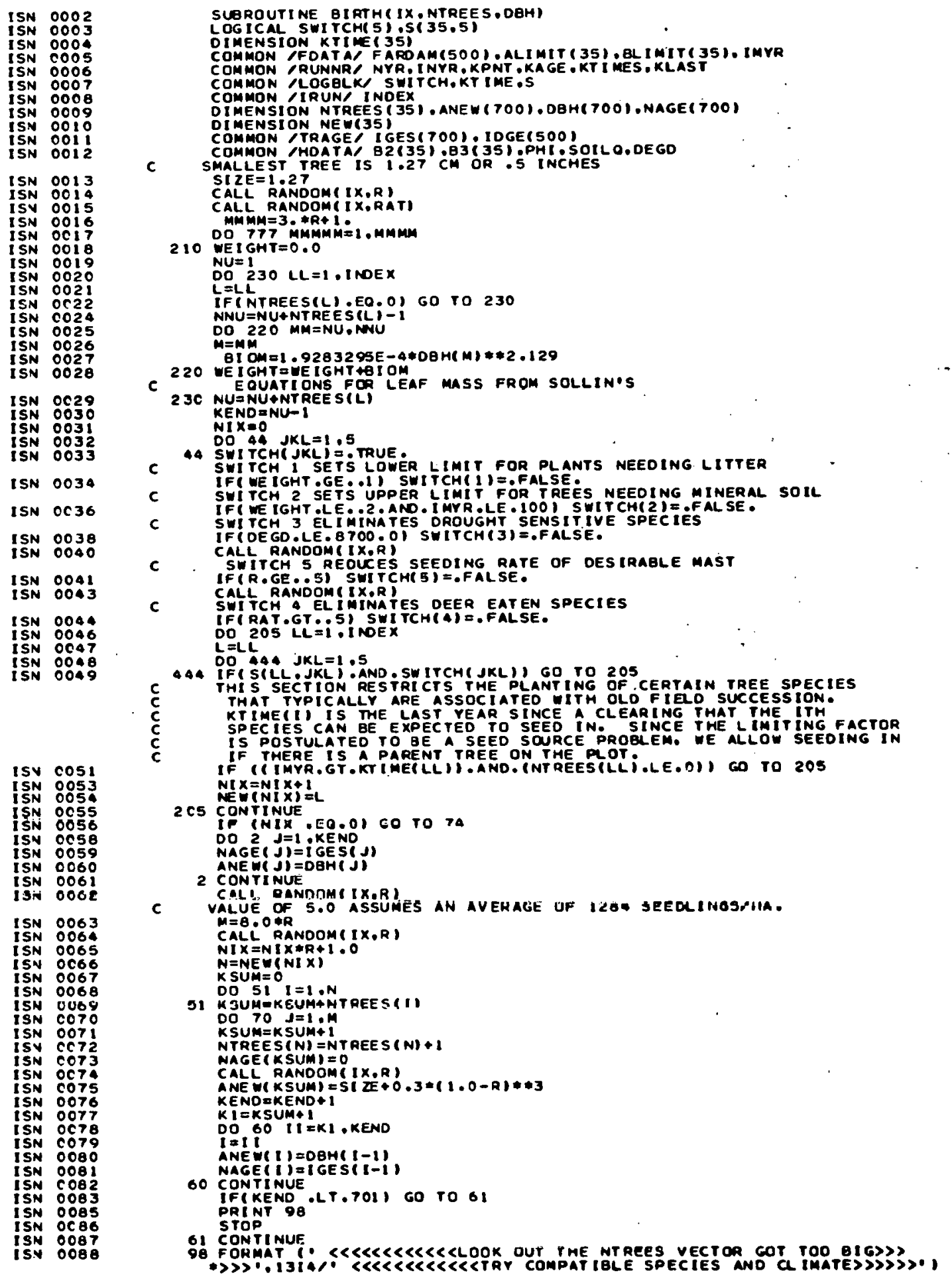




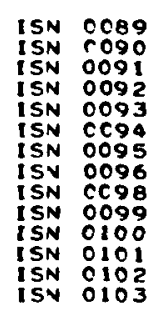

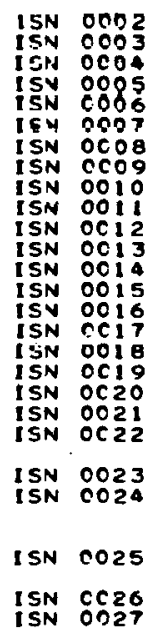

DO $651=1$ KEND

65 DGH II I=ANEWG!

C CONTINUE

N=O

CALL SPROUT (IX,NTAEES, DBH)

CFALL SPROUT!IX.NTAEES,DBHE

DO 100 i=i.KENO

IGE SIII=IGESTII+1.

100 CONTI NUE

RETURN

ENO

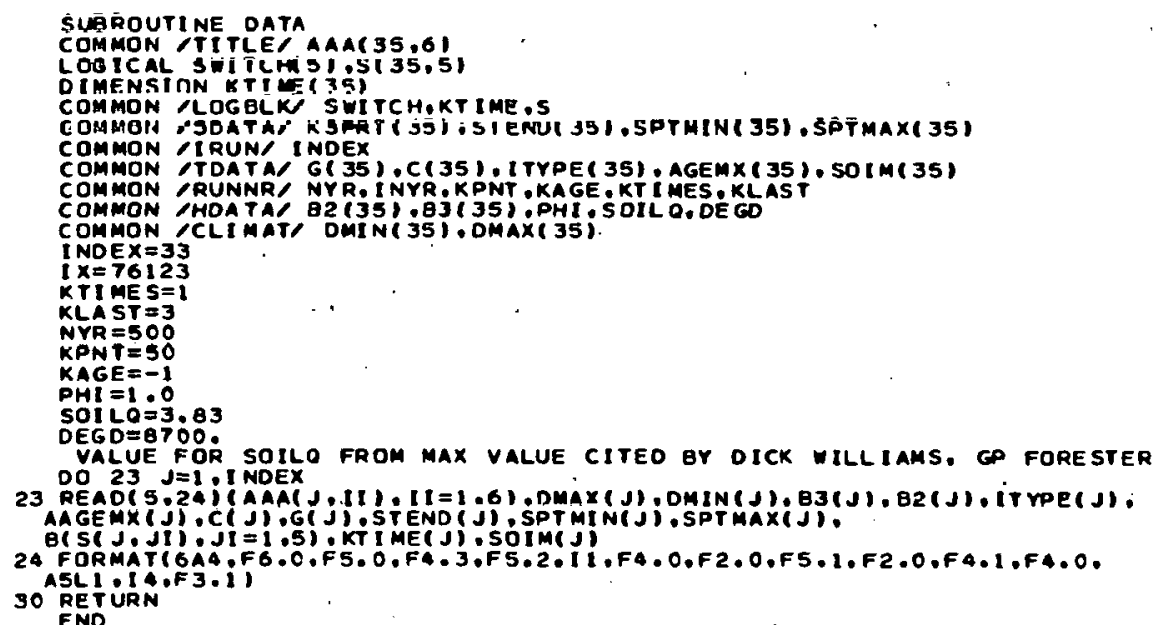


ISN $00 \mathrm{C} 2$

ISN 0003

ISN :004

SUEROUTINE RANDOM(IX, Q)

GE LTRNI $(X)$

RETURN

ISN OCO4

ISN 0005

ISN 0006

ISN OOC

ISN :000

SUAROUTINE GAUSS (IX.S.AM.DEGO)

$z=0.0$

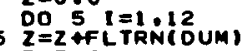

$Z=Z-6 \cdot M$
$D E G D=A M+S * Z$

RETURN

RETUR 


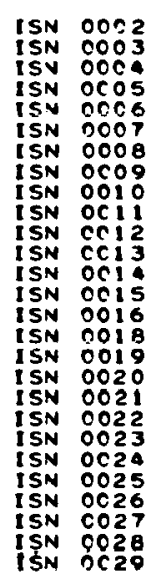

SUBROUTINE INTT (DEN, NTREES D DBHK. NTREEK, JJ)

COMMON ITRUN INOEX

DIMENSION OQH(i). MTREES (1), DEHK( 1 ). NTREEK (1)

COMMON /SDATA'KSPAT (35). STEND(35). SPTMIN (35). SPTMAX( 35 )

COMMN KKILD NOGRO

COMMON

COR

IOGE $J$ ) $=0$.

TOCE J $=0$

10

11 NOGRO $(j)=\dot{C}$

DO $13 \quad J=1$ I INDEX

13 KSPRT $(J)=i$

IF (JJ.GT.11) GO To 1

DO 2 Jai INDEX

2 NTREEK(J)=NTREES ( J)

DO $3 K=1,100$

DBMK (K) =OBH(K)

RETURN

I CONTI NUE

4 DOREESIJi=NTREEK (J)

Do $5 k=1.100$

$(K)=0 B H K(K)$

END DIMENSION OBH(TOO). NTREES (35)

OO $\quad J=1.35$

KOE AO $(J)=$ ?

OBH $(J)=0.0$

I GES S $J=0$

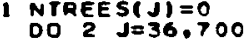

DO 2 J $J=36$.

2 IGES( $J)=0$

IPL OT=IPLOT +1

PDINT IJ.I I th

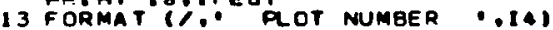

RETURN 


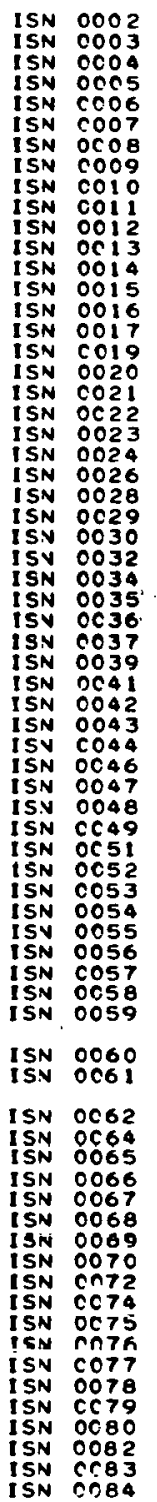

SUBROUTINE KILL(OBH. NTREES, IX)

COMMON FFDATAF FARDAM(50O). ALIMITC.35), BLIMITI35i, IMYR

COMMON GIRUN INDEX

COMMON /SOATAK KSPRT( 35 ). STEND( 35) . SPTMIN(35) . SPTMAXI 35 )

COMMON TTDATAN G(35). C (35). ITYPE (35). AGEMX(35). SOIM(35)

COMMON IKILD' NDGRO (I CO). DDEH(5OD), KOEAD(35). AREA.KD

COMMON /TRAGE, I GES TOO): IDGE(5OO)

COMMON /RUNNR/ NYR,INYR,KPNT,KAGE,KTIMES,KLAST

$10=1$

IDF $=0$

$N=0$

$N B=0$

DO $100 \mathrm{~J}=1$. I NDEX

$N B=N B+K D E A D(J)$

IFINTREES(J).EO.O) GO TO 100

NA $=N+1$

NN = NTREES $(J) \cdot N$

DO 80 II I=NA. NN

$I=I$ I

ALL RANDOMIIX,RI)

IFARDAMI IOFI E EO, I GO TO AS

GO TO 44

42

IF (R1.LE..275) GO TO 50

44 IF(NOGROIIDI.EO. I) GO TO 40

GO TO 80

CALL RANÓOM(IX,R2)

IF (R2.GT.0.368) GO TO BO

50 IF(KAGE.LT.0) GO To 70

$\operatorname{KOE} A D(J)=\operatorname{KOE} A O(J)+1$

$\mathrm{NB}=\mathrm{NB}+\mathbf{1}$

NUP $=K D-N B$

IF ( NUP.EO.O) GO TO 56

DO 55 KK $=1$. NUP

$K=k K$

I $J=K D-K+1$

IF(IJ - GT.500) GD TO 99

DOBH(IJ)=DOBH(IJ-1)

55 CONTINUE

DDBH (NB) = DBH( I)

$K D=K D+1$

o

g8 FORMATI. DEAD TREES VECTOR FILLED. RERUN WITH SMALLER PERIOD GE * THE EN PAINTOUTS (KPNTI:,

KAGE $=-1$

$c$

KAGE $=-1$

THIS IS THE SWITCH TO STUMP SPROUT TREES

DEHCIS= $=-1.00$

BC CONTINUE

1 CO CONTINUE

DO 200 I $I=1,700$

IDI $I$

IF(DBM(I) . EQ 0.0.0) RETURN

IC IF(OBHC I) GT: 0.01 GO TO 200

$D_{K=K K}{ }^{12}$

$K=K K$

DBH $(K)=$ DEH $(K+1)$

120 CONTINUE

CONTINUE $=0.0$

IFE

200 CONTI NUE

RETURN

END 


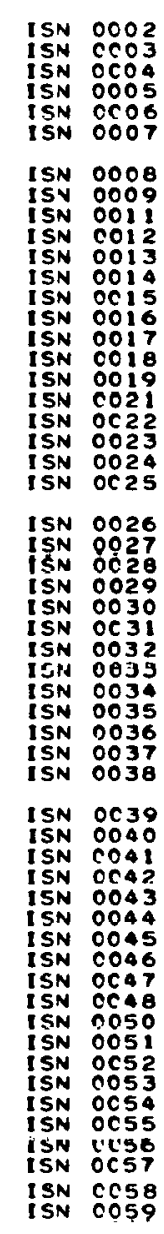

SUBROUTINE FIRE (DEH, MTREES)

FAROAM(500 I ALIMIT (35) OBLIMIT 35) IMYR

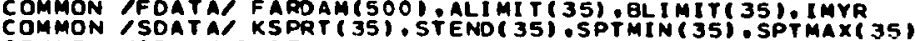
COMMON RRUNA INDEX

c LOG ICAL LOGS

(a)

LOGS= OFALSE.

IF (R.GE.-BSE) GO TO 20

12 FORMAT $15 x_{0}$

Do $15 \mathrm{~J}=1$ i. INDEX

ALI MIT T J $=0.2,7$

15 CONTINUE

CALL CUT IOBH,NTREES.LOGS

RETURN

20 IF (R.GE..9BG) GO TO 30

21 FORMAT ( $5 \times, 0$ MEDIUM FIRE $/)$

DO 25 JeI. I NDEX

$A L I M I T(J)=0$.

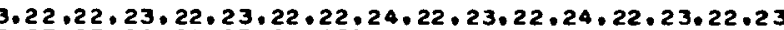

$22^{4} \cdot 22 \cdot 24 \cdot 24 \cdot 22 \cdot 23 \cdot 23,23,23,24,24,23,23,23 i . J$

22 BLI IMT Tis

23 BL(MITij)=25.4

Go

24 BLIMITIJ)=1.7.8

25 CONTINUE

CALL CUT (DBH.NTREES . LOGS)

$\substack{i=0 \\ j=0}$

DO $75=1$. I NOEX

$N A=N+1$

GO TO $135 \cdot 35 \cdot 40,40,35,35,40,35 \cdot 40,35,35,35 \cdot 35 \cdot 40,35 \cdot 35 \cdot 35,40,35,40$

$A \cdot 35.35 \cdot 35 \cdot 35.40 \cdot 40.40 .40 \cdot 35 \cdot 35 \cdot 40.40 .401 . J$

40 DO 35 JJINA . NN

$1 J=1 J+1$

FAROAM(IJ)=JJ

35 CONTINUE

42 CONTI NUE

IMYR=C

RETURN

30 DO $36 \quad J=1$. I NDEX

DO

KSPRTTJI:S

NTREE S(J)=0

36 CONTINUE

DO $37 \quad J=1.700$

DBH IJ J =0.

37 CONTINUE

36 FORMAT ISX. - SEVERE FIRE--ALL TREES WERE BURNED RET URN
FNO 
Appendix A-4

Sample Output of Program FORAR 
SAMRE OUTPUT OF PROGRAM FORAR

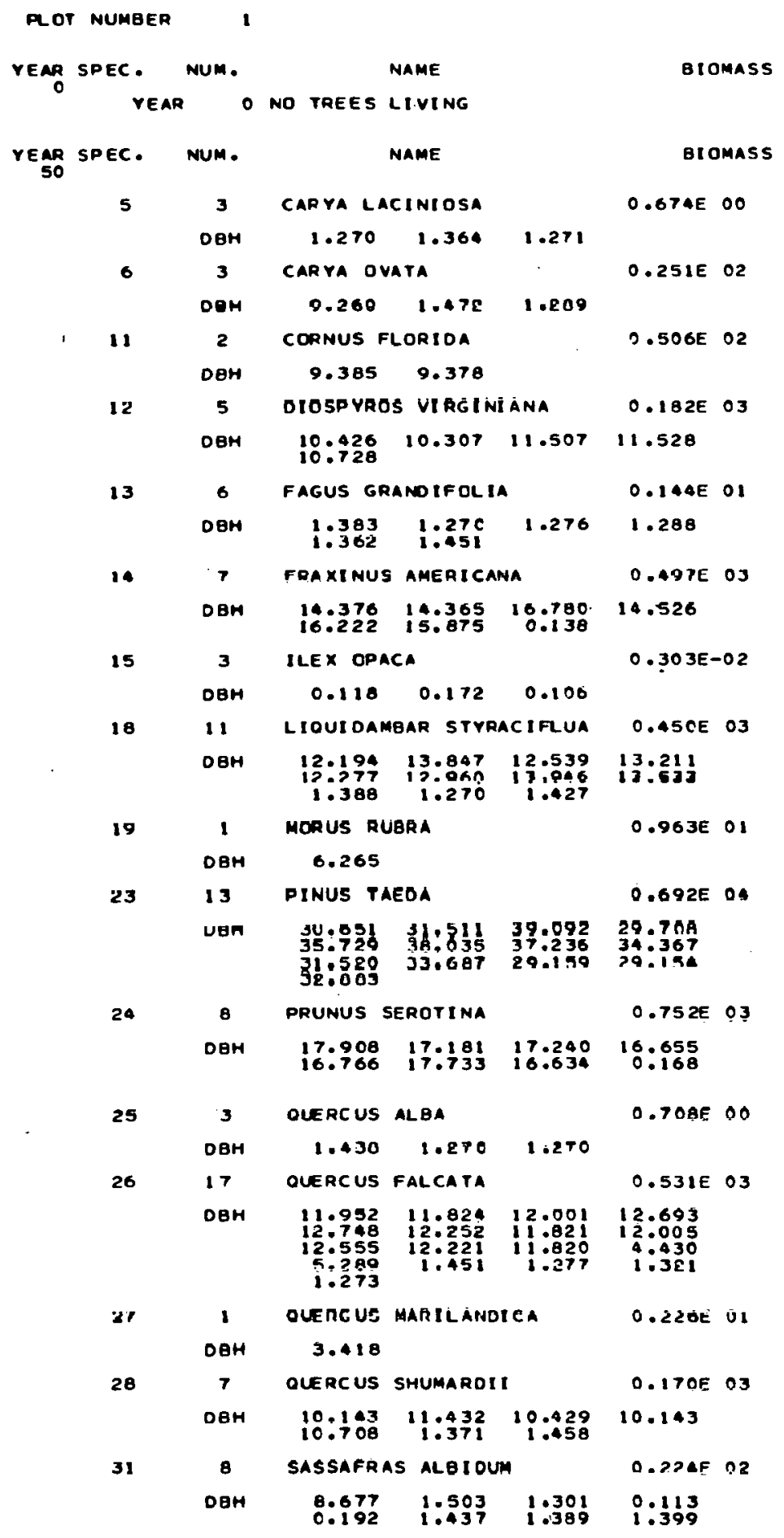




\begin{tabular}{|c|c|c|c|c|c|c|c|}
\hline & 32 & 19 & ULUUS AlATA & & $0.628 E O$ & 03 & \\
\hline & & DBH & $\begin{array}{rr}14.744 & 13.260 \\
12.770 & 12.772 \\
14.269 & 12.770 \\
1.287 & 1: 109 \\
1.528 & 1.298\end{array}$ & $\begin{array}{r}12.779 \\
15.100 \\
0.100 \\
0.128 \\
1.270\end{array}$ & $\begin{array}{r}13.492 \\
14: 663 \\
1: 289 \\
1.270\end{array}$ & & \\
\hline & 33 & 8 & ULMUS AMERI CANA & & $0.560 \mathrm{E}$ & 02 & \\
\hline & & DBH & $\begin{array}{ll}6.175 & 6.507 \\
5.771 & 5.760\end{array}$ & $\begin{array}{l}8.619 \\
0.102\end{array}$ & $\begin{array}{l}6.079 \\
1.570\end{array}$ & & \\
\hline & & 125 & $0.124 E$ O3 METRTC T & TONMA. & LEAF AREA & $=$ & 7.171 \\
\hline $\begin{array}{l}\text { YEAR } \\
100\end{array}$ & SPEC. & Num. & NAME & & Bior & Jmass & \\
\hline & ic & 3 & CELTIS LAEVIGATA & & $0.773 E$ & - & \\
\hline & & OBM & $1.271 \quad 1.368$ & 1.487 & & & \\
\hline & 18 & 2 & LIOUIDAMBAR STYRA & ACIFLUA & $0.460 E$ & 00 & \\
\hline & & DeH & $1.271 \quad 1.359$ & & & & \\
\hline & 21 & $\theta$ & OSTRYA VIRGINIAM & & $0.191 E$ & 01 & \\
\hline & & DEH & $\begin{array}{ll}1.316 & 1.272 \\
1.519 & 1.281\end{array}$ & $\begin{array}{l}1.287 \\
1.299\end{array}$ & 1.392 & & \\
\hline & 23 & 6 & pinus taeoa & & $0.117 E 0$ & 05 & \\
\hline & & DOH & $\begin{array}{ll}63.029 & 70.297 \\
53.833 & 50.296\end{array}$ & 57.756 & 46.638 & & \\
\hline & 26 & 5 & OUERCUS FALCATA & & $0.575 E$ & 03 & \\
\hline & . & DBH & $\begin{array}{l}18.933 \\
1.304\end{array}$ & 20.430 & 19.059 & & \\
\hline & 27 & 2 & OUERC US MARILANDI & $I C A$ & $0.553 E$ & oo & \\
\hline & & DEH & $1.517 \quad 1.316$ & & & & \\
\hline & 32 & 1 & uLMUS alATA & & $0.211 E$ & 00 & \\
\hline & & DeM & 1.270 & & & & \\
\hline & & 27 & $0.148 E$ O3 METRIC T & TONMA. & LEAF AREA & $=$ & 6.904 \\
\hline $\begin{array}{l}\text { YEAR } \\
\text { ISO }\end{array}$ & SPEC. & Num. & NAME & & Bton & DMASS & \\
\hline & 2 & 1 & CARPINUS CAROLINI & I IANA & $0.323 E$ & $\infty 0$ & \\
\hline & & DEH & 1.516 & & & & \\
\hline & 5 & 1 & CARYA LACINIESA & & $0.231 E$ & 00 & \\
\hline & & Uon & I.51T & & & & \\
\hline & 18 & 1 & LIOUI DAMBAR STYYRA & ACI IRUA & $0.214 E$ & 00 & \\
\hline & & DBH & 1.276 & & & & \\
\hline & 21 & 3 & OSTRYA VIRGINIAMM & & $0.768 E$ & - & \\
\hline & & BBH & $1.399 \quad 1.288$ & 1.435 & & & \\
\hline & 23 & 3 & PINUS TAEOA & & $0.130 E$ & 05 & \\
\hline & & DOH & $102.195 \quad 58.679$ & 71.723 & & & \\
\hline & 25 & 6 & OLERC US ALBA & & $0.152 E$ & 02 & \\
\hline & & OBH & $\begin{array}{ll}1.275 & 1.409 \\
1.492 & 1.270\end{array}$ & 1.300 & 1.436 & & \\
\hline & 26 & 11 & QUERCUS FALCATA & & $0.391 E$ & 03 & \\
\hline & & $\begin{array}{c}\text { DBH } \\
\bullet\end{array}$ & $\begin{array}{rl}29.130 & 3.746 \\
0.116 & 0.110 \\
1.291 & 1.281\end{array}$ & $\begin{array}{l}4.503 \\
1.510 \\
1.316\end{array}$ & $\begin{array}{l}3.188 \\
1: 323\end{array}$ & & \\
\hline & 32 & 5 & ULmUS alata & & $0.142 E$ & 01 & \\
\hline & & DBM & $\begin{array}{l}1.284 \\
1.304\end{array}$ & 1.479 & 1.541 & & \\
\hline & 33 & 2 & "ULUUS AMERICANA & & $0.472 E$ & 00 & \\
\hline & & DEH & $1.367 \quad 1.292$ & & & & \\
\hline & & 33 & $0.161 E$ O3 METRIC T & HA. & LEAF AREA & $=$ & 6.7 \\
\hline
\end{tabular}




\begin{tabular}{|c|c|c|c|c|c|c|c|c|}
\hline \multirow{14}{*}{$\begin{array}{r}\text { YEAR } \\
200\end{array}$} & \multirow{2}{*}{$\begin{array}{r}\text { SPEC } \\
2\end{array}$} & \multirow{2}{*}{$\begin{array}{l}\text { NWM } \\
2\end{array}$} & \multicolumn{3}{|c|}{ NAME } & \multicolumn{3}{|c|}{ etomass } \\
\hline & & & CARPINUS & CAROLINI & INA & $0.534 E$ & 00 & \\
\hline & & DEH & 1.502 & 1.286 & & & & \\
\hline & \multirow[t]{2}{*}{7} & 2 & \multicolumn{2}{|c|}{ CARYA TEXANA } & & \multirow[t]{2}{*}{$0.442 E$} & \multirow[t]{2}{*}{00} & \\
\hline & & OBH & 1.316 & 1.270 & & & & \\
\hline & \multirow[t]{2}{*}{10} & $\mathbf{7}$ & \multicolumn{2}{|c|}{ CELTIS LAEVIGATA } & & $0.168 E$ & \multicolumn{2}{|l|}{21} \\
\hline & & DBH & $\begin{array}{l}1.270 \\
1.289\end{array}$ & $\begin{array}{l}1.327 \\
1.439\end{array}$ & $\begin{array}{l}1.268 \\
1.270\end{array}$ & 1.466 & ' & \\
\hline & \multirow[t]{2}{*}{21} & 1 & \multicolumn{2}{|c|}{ OSTRYA VIRGINIANA } & & $0.264 E$ & \multicolumn{2}{|l|}{00} \\
\hline & & OBH & 1.394 & & & & & \\
\hline & \multirow[t]{2}{*}{23} & 2 & \multicolumn{2}{|c|}{ PINUS TAEOA } & & \multirow[t]{2}{*}{$.0 .157 E$} & \multirow[t]{2}{*}{05} & \\
\hline & & DBM & 125.903 & 69.541 & & & & \\
\hline & \multirow[t]{2}{*}{26} & 10 & OUERCUS F & FALCATA & & $.0 .739 E$ & \multirow[t]{2}{*}{03} & \\
\hline & & OBH & $\begin{array}{r}38.387 \\
1.270 \\
1.516\end{array}$ & $\begin{array}{l}1.508 \\
1.302 \\
1.289\end{array}$ & $\begin{array}{l}1.273 \\
1.286\end{array}$ & $\begin{array}{l}1.270 \\
1.272\end{array}$ & & \\
\hline & \multirow[t]{2}{*}{27} & 11 & \multicolumn{3}{|c|}{ PISE GEUS MAPILAHDICA } & $\theta .27 \cdot[$ & 01 & \\
\hline 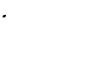 & & OBH & $\begin{array}{l}1.325 \\
1: 542 \\
1: 271\end{array}$ & $\begin{array}{l}1.270 \\
1.270 \\
1.350\end{array}$ & $\begin{array}{l}1.393 \\
1.540 \\
1.389\end{array}$ & $\begin{array}{l}1.276 \\
1.285\end{array}$ & & \\
\hline & 29 & 7 & QUERCUS S & STELLATA & & $0.174 E$ & 01 & \\
\hline & & DEH & 1.281 & $\begin{array}{l}1.454 \\
1.314\end{array}$ & $\begin{array}{l}1.271 \\
1.391\end{array}$ & 1.303 & & \\
\hline & 32 & 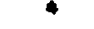 & ILAUE ALA & Ain & & $0.902 \mathrm{E}$ & 00 & \\
\hline & & DEH & 1.331 & 1.270 & 1.303 & 1.313 & & \\
\hline & & 46 & $0.197 E \quad 03$ & METRIC TO & TONAMA. & LEAF AREA & $=$ & 7.786 \\
\hline $\begin{array}{r}\text { VEAR } \\
250\end{array}$ & SPEC. & MUM. & & NAME & & BIO & JMass & \\
\hline & 6 & 5 & CARYA OVA & ATA & & $0.832 E$ & 01 & \\
\hline & & DBH & $\begin{array}{l}3.490 \\
1 . \sin n\end{array}$ & $3 \cdot 159$ & 3.159 & 3.142 & & . \\
\hline & 8 & 7 & CARYA TOM & MENTOSA & & $0.260 E$ & 01 & \\
\hline & & DEH & 1.503 & $\begin{array}{l}1.562 \\
1 . A n A\end{array}$ & $\begin{array}{l}1.574 \\
1.575\end{array}$ & 1.658 & & \\
\hline & 10 & B & C.FLTISIA & AFYITATA & & $\cap, 476 E$ & $\mathbf{D 1}$ & \\
\hline & & DBH & $\begin{array}{l}2.083 \\
2.026\end{array}$ & $\begin{array}{l}1.856 \\
1.897\end{array}$ & $\begin{array}{l}1.865 \\
2.172\end{array}$ & $\begin{array}{l}1.856 \\
1.865\end{array}$ & & \\
\hline & 11 & 4 & COANUS FL & LORIDA & & ठ •B்ठ5E & 01 & \\
\hline & & DBH & 3.344 & 3.124 & 3.418 & 3.124 & & \\
\hline & 15 & 13 & ILEX OPAC & CA & & $0.148 E$ & 02 & \\
\hline & & DBH & $\begin{array}{l}3.421 \\
2.586 \\
1.274 \\
1.319\end{array}$ & $\begin{array}{l}3.54 y \\
2.617 \\
1.271\end{array}$ & $\begin{array}{l}3.563 \\
2.482 \\
1.283\end{array}$ & $\begin{array}{l}3.420 \\
2.454 \\
1.270\end{array}$ & & \\
\hline & 18 & 7 & LIOUI OAME & IBAR STYRA & ICIFLUA & $0.355 E$ & 01 & \\
\hline & & DOII & $\begin{array}{l}1.082 \\
1.886\end{array}$ & $\begin{array}{l}1.843 \\
1.841\end{array}$ & $\begin{array}{l}1.812 \\
1.805\end{array}$ & 1.010 & & \\
\hline & 21 & 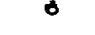 & OSTRYA VI & II RGG I NI ANA & & U.S32E & 01 & \\
\hline & & D8H & $\begin{array}{l}2.615 \\
2.034\end{array}$ & $\begin{array}{l}2.700 \\
2.273\end{array}$ & 2.030 & .2 .090 & $\cdot$ & \\
\hline & 26 & 2 & QUERCUS F & FALCATA & & $0.147 E$ & 04 & \\
\hline & & DBH & 51.207 & 4.339 & & & & \\
\hline
\end{tabular}




\begin{tabular}{|c|c|c|c|c|c|c|c|c|}
\hline & 27 & 15 & QUERC US & MARILANO & ICA & $0.985 E$ & 01 & \\
\hline & & OBH & $\begin{array}{l}2.676 \\
2: 001 \\
1.582 \\
1.656\end{array}$ & $\begin{array}{l}2.363 \\
2: 299 \\
1: 534 \\
1.534\end{array}$ & $\begin{array}{l}2.429 \\
2: 035 \\
1.641 \\
1.549\end{array}$ & $\begin{array}{l}2.417 \\
2: 340 \\
1: 753\end{array}$ & & \\
\hline & 29 & 1 & OUERC US & STELLATA & & $0.377 E$ & 01 & \\
\hline & & $O B H$ & 4.234 & & & & & \\
\hline & 32 & 6 & vimus AL & -ara & & 0.31 te & 02 & \\
\hline & & DBH & $\begin{array}{l}5.226 \\
4.917\end{array}$ & $3: 915$ & 5.346 & 4.915 & & \\
\hline & & 74 & $0.188 E \quad 02$ & 2 METRIC & TONMAA. & LEAF AREA & $A=$ & 0.954 \\
\hline & SPEC. & Num. & & NAME & & eto & omass & \\
\hline & 2 & 4 & CARPINUS & S CAROLIN & I ANA & $0.103 e$ & 01 & \\
\hline & & DEH & 1.569 & 1.386 & 1.270 & 1.270 & & \\
\hline & 5 & 3 & CARYA LA & ACINIOSA & & $0.692 E$ & 00 & \\
\hline & & DBM & 1.376 & 1.279 & 1.293 & & & \\
\hline & 6 & 16 & CARYA OV & VATA & & $0.283 E$ & 03 & \\
\hline & & DBH & $\begin{array}{r}16.100 \\
9.157 \\
6: 815 \\
2.962\end{array}$ & $\begin{array}{r}13.134 \\
6.3338 \\
6.083 \\
3.227\end{array}$ & $\begin{array}{l}9.369 \\
6.737 \\
2.824 \\
2.873\end{array}$ & $\begin{array}{l}9.139 \\
6: 385 \\
2: 8113 \\
2: 909\end{array}$ & & \\
\hline & 7 & $\mathbf{2}^{\circ}$ & CARYA TE & EXANA & & $0.493 E$ & 00 & \\
\hline & & DBH & 1.931 & 1.271 & & & & \\
\hline & 8 & 10 & CARYA TO & OMENTOSA & $\therefore$ & $0.229 E$ & 03 & \\
\hline & & DEH & $\begin{array}{r}15.015 \\
7.965 \\
1.270\end{array}$ & $\begin{array}{r}14.841 \\
7.749 \\
1.352\end{array}$ & $\begin{array}{l}8.482 \\
1.270\end{array}$ & $\begin{array}{l}8.763 \\
1.345\end{array}$ & & \\
\hline & 10 & 11 & CELTIS L & LAEVIGATA & & $0.216 E$ & 03 & \\
\hline & & DEH & $\begin{array}{r}11.299 \\
8.459 \\
4.288\end{array}$ & $\begin{array}{r}10.962 \\
8.625 \\
3.522\end{array}$ & $\begin{array}{r}11.454 \\
8.345 \\
3.508\end{array}$ & $\begin{array}{l}8.471 \\
6.664\end{array}$ & & \\
\hline & 11 & 19 & CORNUS $F$ & LORTOA & & $0.540 E$ & 02 & \\
\hline & & DBH & $\begin{array}{l}7.389 \\
4: 555 \\
1: 605 \\
1.486\end{array}$ & $\begin{array}{r}71159 \\
14880 \\
1: 480 \\
1.486\end{array}$ & $\begin{array}{l}7.297 \\
2.127 \\
1.902\end{array}$ & $\begin{array}{l}4.481 \\
1.918 \\
1.588\end{array}$ & & \\
\hline & 13 & 1 & FAGUS GR & RANDIFOLI & & $0.218 E$ & 00 & \\
\hline & & ОВН & 1.288 & & & & & \\
\hline & 15 & 6 & ILEX OPA & $A C A$ & & $0.260 E$ & 03 & \\
\hline & & DEH & $\begin{array}{r}15.932 \\
7.631\end{array}$ & $\begin{array}{r}13.160 \\
0.102\end{array}$ & 12.649 & 12.019 & & \\
\hline & 18 & 11 & LIOUIDAM & MBAR STYR & AC: I FLUA & $0.498 E$ & 03 & \\
\hline , & & $\mathrm{OBH}$ & $\begin{array}{r}18.288 \\
8.819 \\
5.405\end{array}$ & $\begin{array}{r}18.504 \\
8.557 \\
5.225\end{array}$ & $\begin{array}{r}15.747 \\
8.461 \\
0.101\end{array}$ & $\begin{array}{r}13.078 \\
8.061\end{array}$ & & \\
\hline & 21 & 2 & OSTRYA V & VIRGINI AN & & $0.275 E$ & 00 & $\cdot$ \\
\hline & & DBH & 0.101 & 1.417 & & & & \\
\hline & 25 & 5 & OUERC US & ALBA & & $0.838 E$ & 02 & \\
\hline & & DBH & $\begin{array}{l}11.629 \\
1.477\end{array}$ & 11.258 & 2.438 & 2.455 & & \\
\hline & 26 & 34 & SIERCUS & FALCATA & & $0.482 E$ & 04 & \\
\hline & & DEH & $\begin{array}{r}77.409 \\
15.784 \\
6.992 \\
6.856 \\
5.413 \\
3.723 \\
2.862 \\
2.874 \\
2.921\end{array}$ & $\begin{array}{r}25.001 \\
15.972 \\
6.904 \\
5.721 \\
5.871 \\
3.592 \\
2.864 \\
2.862 \\
2.995\end{array}$ & $\begin{array}{r}15.814 \\
15.789 \\
6.164 \\
5.719 \\
3.911 \\
2.895 \\
2.977 \\
3.148\end{array}$ & $\begin{array}{r}16.623 \\
10.441 \\
5.724 \\
0.029 \\
3.587 \\
2.862 \\
2.862 \\
2.896\end{array}$ & & r \\
\hline
\end{tabular}




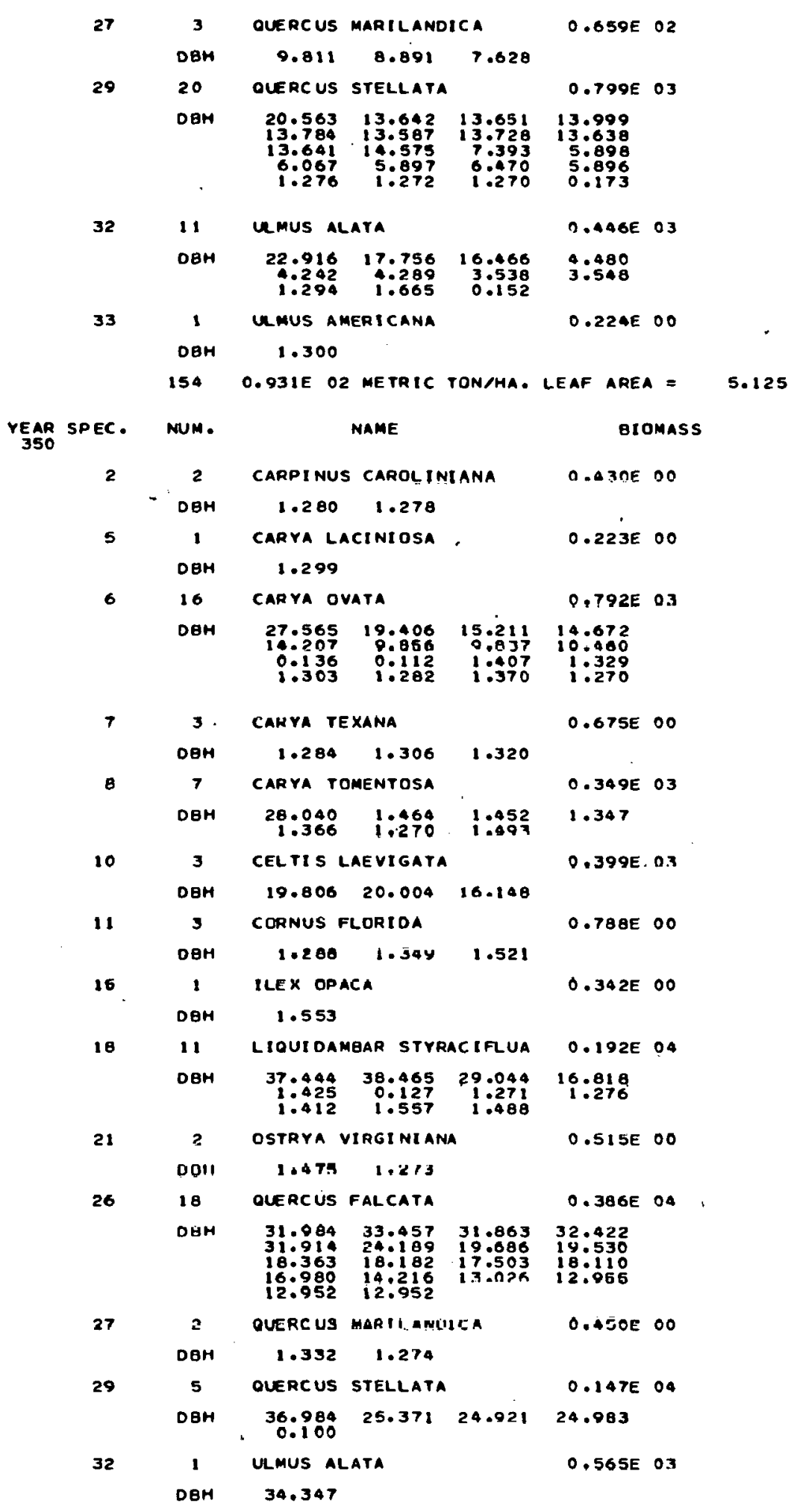




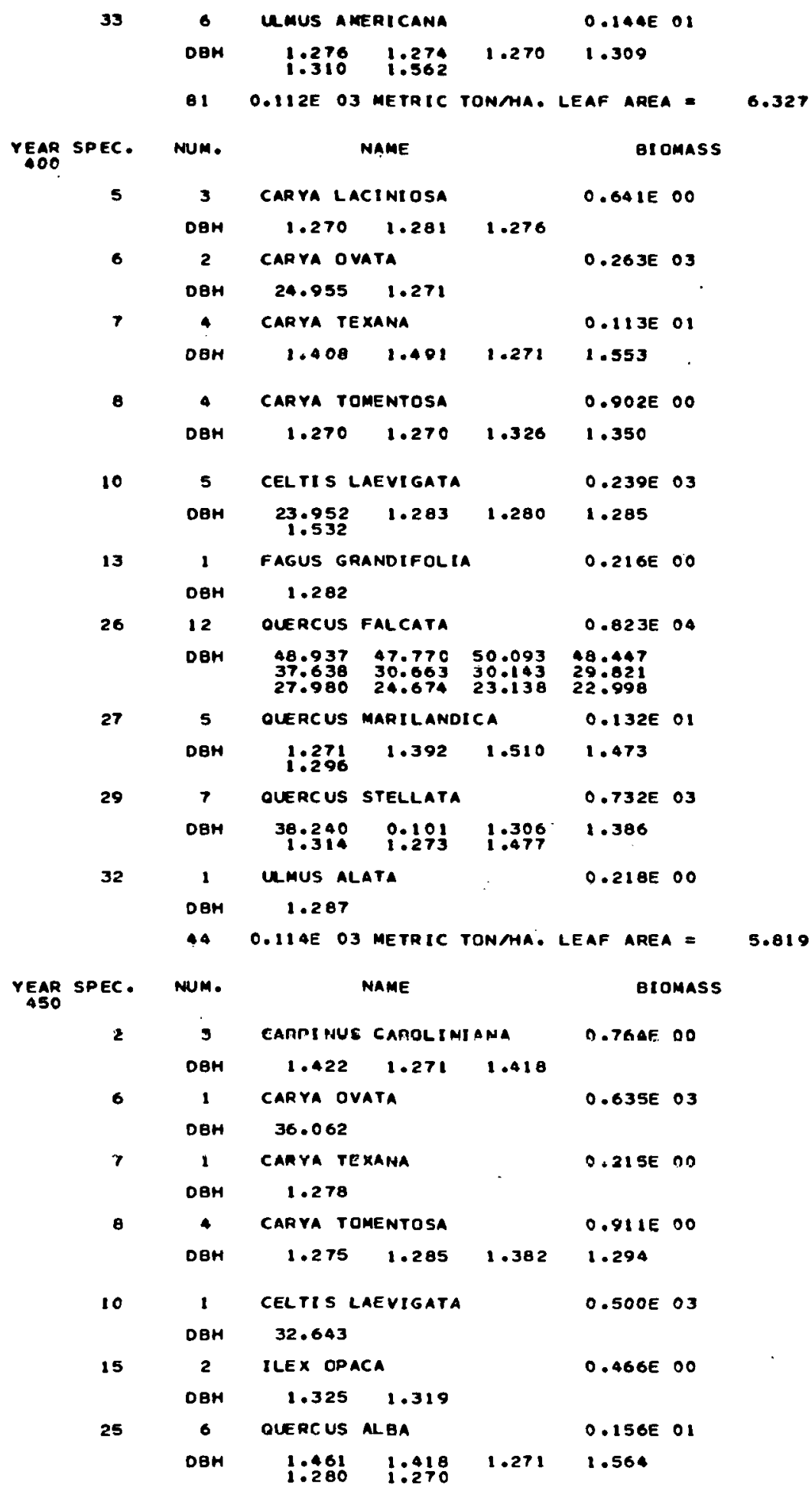




\begin{tabular}{|c|c|c|c|c|c|c|c|}
\hline & 26 & 11 & QUERCUS FALCATA & & $0.799 E$ & 04 & \\
\hline & & OBH & $\begin{array}{rr}64.076 & 69.005 \\
33: 531 & 2: 805 \\
1.473 & 1.458\end{array}$ & $\begin{array}{r}14.239 \\
1.480 \\
1.273\end{array}$ & $11: 929$ & & \\
\hline & 27 & 3 & QUERCUS MARTLANDT & CA & $0.754 E$ & 00 & \\
\hline & & DBH & 1.270 & 1.338 & & & \\
\hline & 32 & 3 & ULuUS alata & & $0.793 E$ & 00 & \\
\hline & & DEH & $1.384 \quad 1.305$ & 1.486 & & & \\
\hline & & 35 & C.11OE O3 METRIC TO & TONMA. & LEAF AREA & $A=$ & 5.177 \\
\hline $\begin{array}{l}\text { YEAR } \\
500\end{array}$ & SPEC. & Num. & NAME & & B10 & amass & \\
\hline & 2 & 1 & CARPINUS CAROLINI & IANA & $0.227 E$ & 00 & \\
\hline & & DEH & 1.309 & & & & \\
\hline & 6 & 1 & CARYA OVATA & & $0.121 \mathrm{E}$ & ne & \\
\hline & & DQH & 47.232 & & & & \\
\hline & 7 & 3 & CARYA TEXANA & & $0.848 E$ & 00 & \\
\hline & & D̈̈Ä & $1+2 ? 1 \quad 1.961$ & 1.89! & & & \\
\hline & 10 & 2 & centis Laevigata & & C.BTTE & 03 & \\
\hline & & OBM & $41.266 \cdot 1.278$ & & & & \\
\hline & 13 & 3 & FAGUS GRANDIFOLIA & & $0.780 E$ & 00 & \\
\hline & & DEH & $1.540 \quad 1.271$ & $1.3 ? 3$ & & & \\
\hline & 15 & 6 & ILEX OPACA & & $0.189 E$ & 01 & \\
\hline & & DEH & $\begin{array}{ll}1.272 & 1.565 \\
1.285 & 1.270\end{array}$ & 1.275 & $\begin{array}{l}1.360 \\
1.282\end{array}$ & & \\
\hline & 21 & 4 & OSTRYA VIRGINIAMA & . & $0.990 E$ & 00 & \\
\hline & & DEM & 1.274 & 1.349 & 1.272 & & \\
\hline & 26 & 3 & OUERC US FALCATA & & $0.119 E$ & 25 & \\
\hline & & DEM & AI.3IK AA, 3日9 & $60.1+1$ & & & \\
\hline & 32 & 7 & LLMUS ALATA & . & 0,1805 & 01 & \\
\hline & & DEH & $\begin{array}{l}1.129 \\
1: 559\end{array}$ & $\begin{array}{l}1.335 \\
1.293\end{array}$ & 1.519 & & \\
\hline & & 32 & 0.167E O3 METRIC TI & TONMA. & I.FAF $\triangle P E$ & $A=$ & 7.284 \\
\hline
\end{tabular}


ORNL/TM-5767

INTERNAL DISTRIBUTION

1-19. S. I. Auerbach

20. R. W. Brocksen

21. R. L. Burgess

22. R. M. Davis

23. F. G. Goff

24. R. A. Harris

25-33. W. F. Harris

34. W. C. Johnson

35. J. M. Klopatek

36-55. D. L. Mielke

56. D. C. Parzyck

57. W. M. Post

58. Herman Postma

59. J. W. Ranney

$$
\begin{aligned}
& \text { 60-63. } \text { D. E. Reichle } \\
& 64 . \text { C. R. Richmond } \\
& 65-74 . \text { H. H. Shugart, Jr. } \\
& 75 . \text { E. G. Struxness } \\
& 76 . \text { R. I. Van Hook, Jr. } \\
& 77 . \text { P. Van Voris } \\
& \text { 78-83. } \text { D. C. West } \\
& \text { 84. } \text { Biology Library } \\
& \text { 85-86. } \text { Central Research Library } \\
& \text { 87. } \text { ORNL Patent Office } \\
& \text { 88-89. Laboratory Records Dept. } \\
& \text { 90. Laboratory Records, ORNL-RC } \\
& \text { 91. ORNL Y-12 Technical Library }
\end{aligned}
$$

\section{EXTERNAL DISTRIBUTION}

92. D. B. Botkin, Woods Hole Oceanographic Institute, Woods Hole, MA

93. Edward Buckner, Dept. of Forestry, University of Tennessee, Knoxville, TN 37916

94. R. D. Cooper, Division of Technology Overview, ERDA, Washington, DC 20545

95. Boyd Dearden, Dept. of Forestry, University of Tennessee, Knoxville, TN 37916

96. Dale Hein, Dept. of Fishery and Wildl ife Biology, Colorado State University, Ft. Collins, CO 80523

97. J. Frank McCormick, Ecology Program, 408 10th Street, Knoxville, TN 37916

98. J. T. Tanner, Ecology Program, 408 10th Street, Knoxville, TN 37916

99. G. M. Van Dyne, Natural Resources Ecology Laboratory, Colorado State University, Ft. Collins, CO 80523

100. Research and Technical Support Division, ERDA-ORO

101-127. Technical Information Center, Oak Ridge, TN 37830 